\title{
Energy Storage Applications to Address the Challenges of Solar PV and Wind Penetration in Indonesia: A Preliminary Study
}

\author{
Mukhamad F. Umam ${ }^{1}$ *, Sesi Selia ${ }^{2}$, Amrullah F. Sunaryo ${ }^{2}$, Muhammad R. Al Asy'ari ${ }^{2}$ \\ ${ }^{1}$ PPSDM Migas, J1. Sorogo No.1, Kampungbaru, Karangboyo, Kec. Cepu, Kabupaten Blora, Jawa Tengah 58315, Indonesia \\ ${ }^{2}$ Enerka Bhumi Pratama, Conclave Simatupang, Cilandak Estate, RT.1/RW.5, Cilandak Timur., Pasar Minggu, Jakarta \\ Selatan, Daerah Khusus Ibukota Jakarta 12560 Indonesia
}

*Corresponding Author: mukhamad.umam@esdm.go.id

\section{Article History}

Received 1 June 2021

Accepted 22 February 2022

Available 27 February 2022

\begin{abstract}
Indonesia intends to increase the renewable energy ratio to at least $23 \%$ from the energy mix generated by 2025. This target is also in line with the Paris Agreement that Indonesia ratified in October 2016. However, renewable energy capacity has not been significant, as $11.38 \%$ of the total on-grid power capacity (MEMR, 2021). More than $90 \%$ of renewable comes from hydropower and geothermal, and only a limited capacity comes from wind and solar energy. On the other hand, wind and solar energy potential are enormous for energy generation in Indonesia. One of the barriers that hinder the utilization of both energy resources is their intermittent nature, so they are not economically profitable and can disrupt the existing power grid. Energy storage systems (ESS) can reduce this intermittent problem as frequency regulators and voltage support to the grid. This paper reviews the potential and challenges of energy storage and renewable power generation, especially wind and solar power. This paper also outlines lessons learned from energy storage systems that have been implemented and are still under development. The study discussion focuses on the types of energy storage suitable for applications in Indonesia.
\end{abstract}

Keywords:

renewable energy, solar PV, electricity grid, off-grid electrification, economic development

\section{Introduction}

Indonesia's energy needs are estimated to double from 13 MTOE in 2018 to 23.9 MTOE in 2025 (BPPT, 2020). The demand for electrical energy will continue to increase with Indonesia's economic growth rate. On the other hand, fossil fuels as primary energy sources should gradually be reduced to minimize greenhouse gases (GHG). Thus, renewable energy-based power plants' development is encouraged to meet the demand for electrical energy. However, renewable energy development is still far from the target despite abundant potential reserves. The challenges of renewable development must be resolved for the success of renewable energy development in Indonesia.

\subsection{Renewable Energy Target}

The Indonesian government has targeted new and renewable energy at least $31 \%$ in the primary energy mix by 2050 (The Republic of Indonesia, 2014). This target is used as a foundation for other energy policies, such as the National Energy General Plan (The Republik of Indonesia, 2017) and the Electricity Supply Business Plan (PLN, 2019). With an estimated energy demand of 400.3 megatonnes of oil 
equivalent (MTOE) in 2025 (The Republik of Indonesia, 2017), this requires a supply of new and renewable energy of 92.3 MTOE. Of these, 69.2 MTOE or approximately 45.2 Gigawatt (GW) is used to generate electricity (The Republik of Indonesia, 2017). This supply comes from bioenergy of 33.8 MTOE, water 24.9 MTOE, geothermal 21.8 MTOE, solar 4.3 MTOE, wind 1.8 MTOE. The rest will be fulfilled by micro-hydro, and other renewable sources with 5.2 MTOE and 0.5 MTOE, respectively (The Republik of Indonesia, 2017).

Furthermore, this target is also in line with the nationally determined contribution (NDC) to the United Nations Framework Convention on Climate Change (UNFCC) (The Republic of Indonesia, 2016b). Indonesia is committed to reducing greenhouse gases (GHG) unconditionally by $29 \%$ and conditionally by $41 \%$ of the business as usual (BAU) scenario in 2030 (The Republic of Indonesia, 2016a). Suppose the target of the renewable energy mix is achieved. In that case, it is estimated that Indonesia's GHG emissions can be reduced by around 314 metric tons of carbon dioxide (MtCO2) than the projected GHG level of $2.869 \mathrm{MtCO} 2$ in 2030 using the BAU scenario (Kemenhut, 2018).

\subsection{The Development of Solar and Wind Energy}

Many potential renewable energy resources are available in Indonesia, but only a few are technologically mature and proven to be developed further. Through the state-owned electricity company (PLN), the government plans to build several power plants with energy sources from hydro, geothermal, wind, solar, biomass, maritime, and biofuel (PLN, 2019).

Table 1. New and renewable energy resources (BPPT, 2019; MEMR, 2021).

\begin{tabular}{|c|c|c|c|c|}
\hline Energy Type & Resources & Potential & $\begin{array}{l}\text { Installed } \\
\text { Capacity }\end{array}$ & Utilization \\
\hline Solar energy & $4,80 \mathrm{kWh} / \mathrm{m} /$ day & $207,898 \mathrm{MW}^{* *}$ & $153.5 \mathrm{MW}^{*}$ & $0.07 \%$ \\
\hline Wind energy & $9,286.61 \mathrm{MW}^{* * *}$ & $970 \mathrm{MW}$ & $154.3 \mathrm{MW}^{*}$ & $1.66 \%$ \\
\hline
\end{tabular}

The Indonesian government has initiated solar energy utilization since the 1970s with the solar home system (SHS) method (Retnanestri \& Outhred, 2015). Meanwhile, the first on-grid centralized solar power plants started in 2013 with a power of $1 \mathrm{MWp}$ in Bali (MEMR, 2013). Indonesia's potential as a tropical country that passes through the equator is enormous, namely $4.8 \mathrm{kWh} / \mathrm{m} 2$ or $207,898 \mathrm{MW}$ (Rumbayan et al., 2012). In contrast, the total installed capacity of solar power plants to date is 153.5 MW or $0.07 \%$ of its total potential, as shown in Table 1 . To meet the 2025 target, the government plans to add rooftop solar power plants and floating solar power plants such as the $145 \mathrm{MW}$ Cirata Floating PV Project (MEMR, 2021).

Furthermore, wind energy has been used as an energy source for water pumps and lighting for more than 30 years in Indonesia. This country's estimated wind power potential is around 9,286.61 MW, with wind speeds ranging from 2-6 m/s (Purwanto et al., 2006). Until 2020, the installed capacity of wind power plants in Indonesia is $154.3 \mathrm{MW}$ or $1.66 \%$ of its resources, as shown in Table 1. Two mediumcapacity power plants as the main contributors are the Sidrap plant (75 MW) operating in 2018 and the Jeneponto plant (72 MW) operating in 2019 (PLN, 2019).

Indonesia has set ambitious targets for renewable energy development and fossil-based power plant reduction by 2050. BPPT (2020) estimates that the new renewable energy mix target's achievement will reach $19.9 \%$ in 2030 and $22.2 \%$ in 2050 . However, these predetermined targets may not be fully achieved (Sarjiya et al., 2020). Several factors indicated to be obstacles to renewable energy growth are economic, social, immature technology, and integration with existing networks (Arafah et al. 2018; Burke et al. 2019; Umam et al. 2018). Economic and social factors have been widely discussed in the literature, but limited publication in Indonesia covers technology and integration of these energy sources. Hence, this paper will focus on the last two problems. 


\subsection{The Objective of the Study}

This paper investigates the potential and challenges of developing renewable energy in Indonesia, especially solar photovoltaic and wind turbines. This paper also examines the latest developments in energy storage technology as a potential solution to help overcome problems arising from intermittent energy sources. Several examples of success stories and unsuccessful energy storage implementation are also presented to take lessons from their application in Indonesia in the future. This study also models three scenarios: solar PV only, solar PV plus battery, and hydropower plant. The results of these models are used to compare each design and show that the development of energy storage provides more benefits and is economically feasible.

\section{Method}

This paper investigates the potential for future renewable energy development in Indonesia by reviewing documents, policies, reports, current developments of renewable energy and energy storage technologies. This paper also estimates the economic aspect of developing renewable using the System Advisor Model (SAM) developed by The National Renewable Energy Laboratory (NREL).

\subsection{Literature Review}

Paper reviews' primary objective is to map the potential and challenges of solar PV, wind and energy storage in Indonesia and abroad from articles, books, reports and other sources. A literature review describes the theory, findings and other research materials obtained from reference materials to serve as the basis for research activities to formulate an exact frame of mind from acquiring the problem to be investigated. For the literature review, the authors selected the top 100 search results on google scholar with the keywords "PV challenges and potentials in Indonesia," "wind challenges and potentials in Indonesia," "energy storage challenges and potentials," and "lesson learned energy storage."

\subsection{Modeling}

This research builds three models for developing 20 MW power plants, PV modules only, PV modules with batteries and PV modules with hydropower plants. SAM combines time-series weather data and system specifications to analyze electricity production from potential renewable energy systems to assist decision-makers in renewable energy system design and project economics. The model built by SAM uses system cost, compensation, financing and incentive data in annual cash flows to calculate the leveled energy cost, net present value, payback period, internal rate of return and potential project revenue. The SAM modeling flow chart is shown in Figure 1.

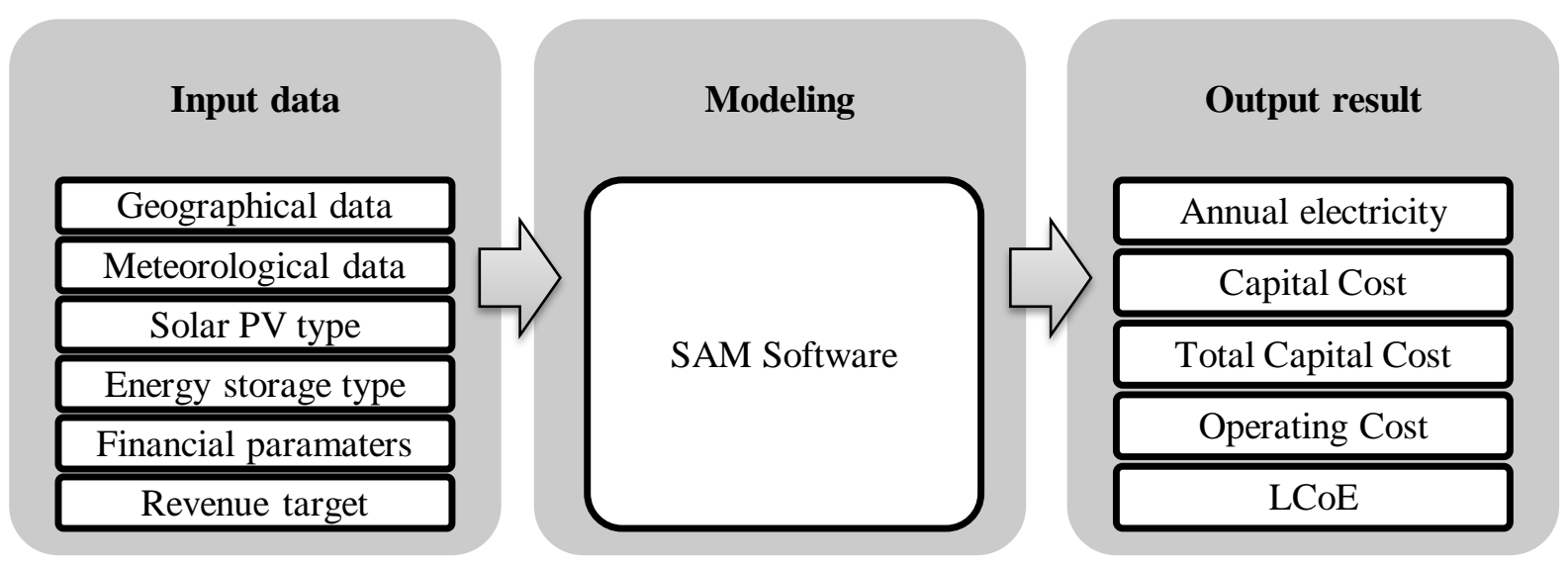

Figure 1. Flow chart of modeling input and output by SAM software. 
The SAM also estimates energy production and energy costs for solar PV systems connected to the grid to calculate the capital cost, total capital cost, fixed operating cost, annual energy (year 1), and the LCoE., while the LCoE is calculated using the following equation 1 (Short et al.,1995).

$$
\mathrm{LCoE}=(\mathrm{FCR} * \mathrm{TCC}+\mathrm{FOC}) / \mathrm{AEP}+\mathrm{VOC}
$$

Where:

TCC : Capital cost $(\$)$

FOC : Fixed annual operating cost $(\$)$

VOC : Variable operating cost $(\$ / \mathrm{kWh})$

FCR : Fixed-charge rate

AEP : Annual electricity production $(\mathrm{kWh})$

\section{Solar and Wind Energy Opportunities and Challenge}

\subsection{Solar $P V$}

Indonesia is a tropical country that gets solar irradiation throughout the whole year. The country's solar power is estimated at $3.2 \mathrm{kWh}-6.2 \mathrm{kWh} / \mathrm{m}^{2}$ a day (Nababan et al., 2019). The potential for solar power for a solar cell or Photovoltaic (PV) system is estimated at 500 GW (IRENA, 2017). Hence, many solar power plants have been developed in several regions in Indonesia, supported by the excellent potential for solar energy, which reaches $4.80 \mathrm{kWh} / \mathrm{m} /$ day. Moreover, several Indonesian areas, such as eastern Indonesia, have relatively high radiation levels with an average of $5.46 \mathrm{kWh} / \mathrm{m}^{2} / \mathrm{month}$ (Adam \& Miyauchi, 2019). The total installed capacity of solar PV in Indonesia is $153.5 \mathrm{MW}$, or $0.07 \%$ of its total potential (MEMR, 2021).

PV cell systems provide a good performance increase compared to other designs because solar PV can fully utilize solar energy that is available almost 10 hours daily in Indonesia (Umam et al. 2021). Solar PV can also be maximized with a distributed PV system where solar energy will be connected to the grid system. The off-grid solar PV development process is considered the solution for Indonesia's electrification problem (Retnanestri \& Outhred, 1993). Off-grid solar PV systems were also identified as the best energy option for rural area electrification (Irfan et al., 2019). Off-grid solar PV is targeted to meet the electricity needs of remote or rural communities (Blum et al., 2013). Dwipayana et al. (2021) insisted that for the sustainability of off-grid solar power, maximizing the share of solar power plant beneficiaries as early as possible is very important. Off-grid solar PV is targeted to meet the electricity needs of remote or rural communities, for remote or rural areas. Solar PV can be applied with a hybrid system to generate more electricity. The development of a solar PV system is cost-efficient, while its price is the primary consideration for the customer to decide the PV size (Adam \& Miyauchi, 2019). Some of these advantages will impact the Net Present Value (NPV), which means that it will speed up the return on capital so that the process of balancing the selling price will occur quickly.

The development of solar PV power plants provides several advantages impact. First, solar PV development to replace fossil-based power plants will benefit the environment. The reduction rate of greenhouse gasses (GHG) from applying one $\mathrm{kWp}$ of the solar system is estimated at $1.66 \mathrm{~kg}$ of $\mathrm{SO}^{2}$; $3.46 \mathrm{~kg}$ of $\mathrm{NO}_{\mathrm{x}} ; 1295 \mathrm{~kg}$ of $\mathrm{CO}^{2}$; and $91 \mathrm{~kg}$ of ash per year (Tarigan et al., 2015). Second, the operation of solar PV does not disturb the residents in case of environmental quality (Dwipayana et al., 2021). Third, solar PV creates energy security and makes Indonesians less dependent on fossil energy. Fourth, the barrier of transportation of fossil fuel supply for diesel generators to remote areas and its harmful impact on the environment is eliminated (Shezan et al., 2018). Fifth, the development of solar power plants also impacts the economic sector. Empowerment of the surrounding community will help improve the economy in the area. Infrastructure development will also have a good impact on the tourism sector.

However, solar energy development cannot be separated from several challenges that must be faced. The main challenge of solar PV development is the weather conditions. The periods of high-level 
radiation potentially depend on the weather condition, which is relatively difficult to predict (Tarigan et al., 2015). If there is rain or no sun, the system only runs for a short time, so this solar power cannot meet daily electricity needs. Solar PV works at best when backed up by peak load generators power a region. This generator serves as a backup during peak demand when there is no sun (Fairuz et al., 2018). This problem occurs due to a lack of energy storage to accumulate solar irradiation. Energy storage is still not large enough and primarily supports off-grid systems. The intermittency problem cannot be resolved because there is not enough storage system to operate exclusively for 24 hours every day. This lack of energy storage means no backup for generators when electrical energy is required during high usage hours.

Moreover, several non-technical challenges are also hinder the development of solar PV. First, the developer should comply with government permits, government policies, regulations or policies in the area concerned, land approval and environmental impact. Second, Indonesia is an archipelagic country, so the delivery of goods and distribution of products becomes difficult, especially for remote areas. Third, the difference in irradiation for each potential area so that not all sites can be placed for solar power plants (Dwipayana et al., 2021). Fourth, developing solar energy requires a considerable initial investment, high transportation costs, long delivery times (Sukarso \& Kim, 2020), high equipment costs (Soonmin et al., 2019; Syanalia \& Winata, 2018; World Bank, 2007). It also has considerable grid installation costs, repair costs and maintenance costs are also high, making solar energy expensive (Al Matin et al., 2019). Fifth, without incentives from the government for a small-scale grid-connected PV system, the investment return is as long as 17,6 years before it starts to produce a profit (Tarigan et al., 2015). The return-on-investment system is seen as taking a very long time to stabilize the selling price. Sixth, the pace of development is delayed because the market is mainly regulated by PLN (Syanalia \& Winata, 2018). PLN has also dominated the sale of electricity. Seventh, the lack of information and knowledge from PLN for the public about solar energy (Alifia \& Fraser, 2021). Thus, the increase in Solar Power capacity is not always accompanied by the capacity development of communities in remote areas (Dwipayana et al., 2021). Therefore, the lack of human resources will complicate the growth and sustainability of solar power in a future project.

Indonesia has implemented a FiT (Feed-in Tariffs) policy for solar power to answer these challenges. This policy, by far, is the most effective policy measure to support the rapid development of distributed grid-connected PV systems (Outhred \& Retnanestri, 2015). This policy creates a higher selling price of electricity produced by solar PV because it is now adjusted with the production cost and the initial capital of solar power development. However, this policy is revised to the island's location. The islands that are far and challenging to reach will get relatively high prices.

\subsection{Wind Energy}

Indonesia owns relatively high wind energy potential is for extensive utilization, and it is available all year-round (Muliadi et al., 2015). The Ministry of Energy and Mineral Resources (MEMR) estimated the total wind energy capacity in the country is around 9.29 GW. However, the installed capacity of wind power plants in Indonesia is $154.3 \mathrm{MW}$ or $1.66 \%$ of its resources until 2020 . Two mediumcapacity power plants as the main contributors are the Sidrap plant (75 MW) operating in 2018 and the Jeneponto plant (72 MW) operating in 2019 (PLN, 2019). Indonesia has several advantages as an archipelago and has around 17,000 islands with a stretch of coastline covering an area of 81,000 km, which wind speed in Indonesia is pretty good and stable (Sari \& Kusumaningrum, 2014). Moreover, ocean wind has more significant potential than ocean currents (Purba et al., 2014). The development of wind power projects is intended so that the electrical trade can reach remote areas. For instance, several locations that have applied wind turbines for generating electricity are the shore of the northern and southern part of Java Island, the eastern part of Madura island, the south and north part of Sulawesi Island and some parts of the Nusa Tenggara islands (Martosaputro \& Murti, 2014).

Wind power development in Indonesia will benefit the population's positive social and economic impacts. For example, the growth of the wind power industry can help local communities' empowerment by creating job opportunities. Also, the application of wind-based energy has a good effect on the 
environment because it can create a clean and healthy atmosphere, reducing harmful gas emissions. Thus, green energy will have a good impact on human health and improve the welfare of society (Pristiandaru \& Pambudi, 2019). The market price for purchasing electricity from the wind power plant has been regulated by MEMR Regulation No. 12 in 2017. Pricing policies such as feed-in tariffs with provisions that guarantee investors will get a reasonable price can boost wind power generation policies at competitive prices and encourage developing wind power (Pristiandaru \& Pambudi, 2019).

Furthermore, the utilization of wind energy power has proven several advantages. First, wind power generation could stimulate development in rural areas that do not have a supporting system like infrastructure to transport other fuel supplies is unavailable (Pristiandaru \& Pambudi, 2019). Plant facilities in the wind power industry area will develop rapidly to encourage infrastructure progress. Second, wind power is a clean option for mitigating environmental and health problems from carbon emissions. To achieve sustainable development, they can also overcome the increasing energy demand (Noviani, 2019). Third, wind energy is the most efficient source of energy because there is no fuel cost (Pristiandaru \& Pambudi, 2019).

On the other hand, wind energy development also has several challenges. First, although it has much lower emissions, the production price is still higher than the non-renewable energy in Indonesia (Hidayatno et al., 2019). In the process, the beginning of wind farm construction in Indonesia requires high costs because the equipment is still limited and also about the land acquisition. The International Renewable Energy Agency (IRENA) shows that the expenses are around USD 3 million to USD 4 million per MW to construct offshore wind turbines (Sector, 2012). Also, the wind turbines used are expensive because they are imported from abroad, and if the spare parts are needed lacking or damaged, they are not always ready in the local market. Many areas with the potential are challenging to reach because of their difficult access, making the funding for wind energy immense. Furthermore, Pristiandaru \& Pambudi (2019) found that a lack of funding can make it hard to hire skilled technical workers or train new workers.

Second, the intermittency of weather and wind, such as low wind speed and fluctuating wind stability. The main barrier is that the average wind speed in Indonesia is relatively low, making it more challenging to produce electricity that can use on a large scale (Pristiandaru \& Pambudi, 2019). Integrating Wind Power Plants (WPP) to interconnected power systems is quite challenging because of the wind intermittency that affects the wind power plants WPP output power (Ajami et al., 2019). Several studies have shown that intermittency is not the unanswered question to develop wind power (Ren et al., 2017). The fluctuation of output power itself can be dangerous for the power system's stability (Ajami et al., 2019). The inability of wind energy to meet daily needs occurs because wind energy storage is still minimal. The storage power or spare generator set is still insufficient not to meet household electricity needs. Energy storage must also be strategically placed to make it more efficient.

To answer these challenges, particularly in standalone applications, the hybrid of solar PV and wind generation systems has become a desirable solution (Al Badwawi et al., 2015). These are also modeled as types of power plants in the standalone and hybrid systems despite the quantity and quality still needing improvement (Martosaputro \& Murti, 2014; Stich et al., 2014). Combining solar PV and wind turbines can provide better reliability and more economical because the weakness of one system can be complemented by the strength of the other (Al Badwawi et al., 2015). Therefore, hybrid solar panels and wind systems with battery storage for electrification and energy storage are needed to meet daily electricity needs.

\section{Energy Storage Opportunities and Challenge}

An energy storage system can capture energy produced by the source of energy/generator at one time and can be used later if needed. Many technologies can supply short-term energy storage, while few can provide much longer endurance. Gür (2018) and Braff et al. (2016) asserted that energy storage is acknowledged as a sixth value chain in the current value chain for electricity, i.e., generation, fuel, transmission, distribution and services. They also found that energy storage is a profitable alternative 
to the traditional infrastructure, especially for substations, transmission and distribution lines. It utilized distributed energy storage for local grids, or microgrids, to help regulate energy supply and demand while facilitating distributed renewable energy. Based on the Author's research, various energy storage types have already been summarized, as illustrated in Figure 2.

\section{Energy Storages Variety of Type}

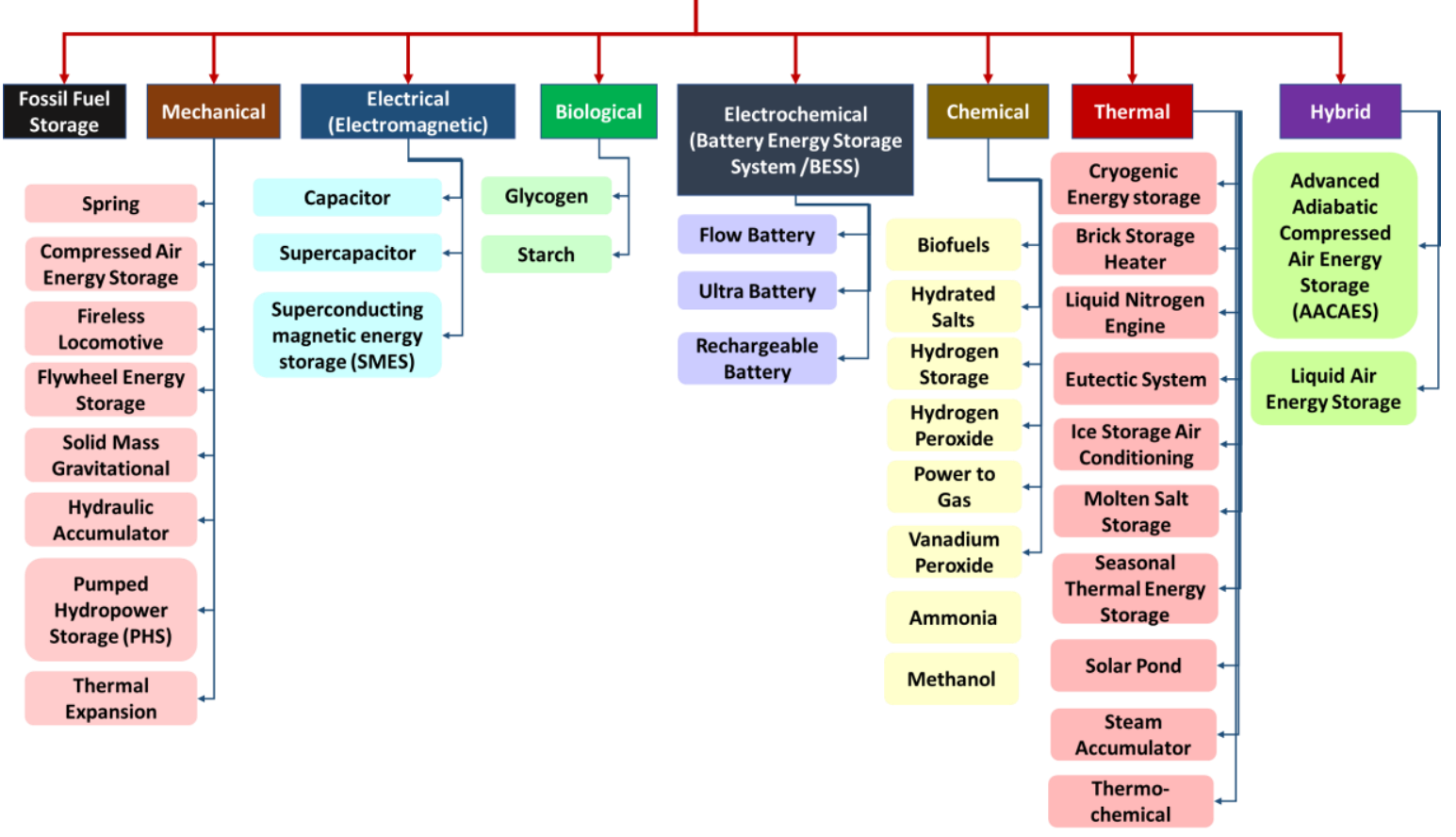

Figure 2. Variety types of energy storage recapitulation (European Commission, 2017; NYISO, 2017).

Nonetheless, not all types of energy storage can be addressed to tackle the renewable energy intermittency problem for Indonesia's application. Thus, the authors map a suggestion of energy storage types that can be implemented to solve those challenges. This study selects four energy storage technologies by considering the most critical qualitative criteria: Indonesia's technological and natural resources. This study also considers technical maturity, load management for medium-scale power plants, environmental impact and power quality from available energy storage. From energy storage types illustrated in Figure 2, four types of energy storage are categorized as mature technology discussed in this research. They are Pumped-hydro Energy Storage (PHES), Compressed-air Energy Storage (CAES), Flywheel Energy Storage (FES) and Li-ion battery. Furthermore, Figure 3 shows PHES and battery storage have the highest implementation worldwide among other types of energy storage (Aneke \& Wang, 2016).

\subsection{Pumped Hydro Energy Storage}

Traditional hydro-based electricity has a confined future as a reliable energy source due to the availability of resources and considerations regarding natural river flow disturbances. Nonetheless, the pumped-hydro energy storage (PHES) system can become is a substantial chance for future reliable energy opportunities. Solar power generation is dynamic, with the global electricity production around $50.6 \%$ from the total power production in 2013 (Liu, 2015). Thus, there is a need for a significant amount of further energy storage, such as Li-ion batteries and PHES. Both energy storage are the main contenders, while PHES is the leading energy storage technology, with $97 \%$ of the global installation of $160 \mathrm{GW}$ and over $99 \%$ of the stored energy (IEA, 2021). Furthermore, PHES is a mature off-shelf technology and significantly cheaper than any large-scale energy storage competitors already implemented globally (Rehman et al., 2015). 

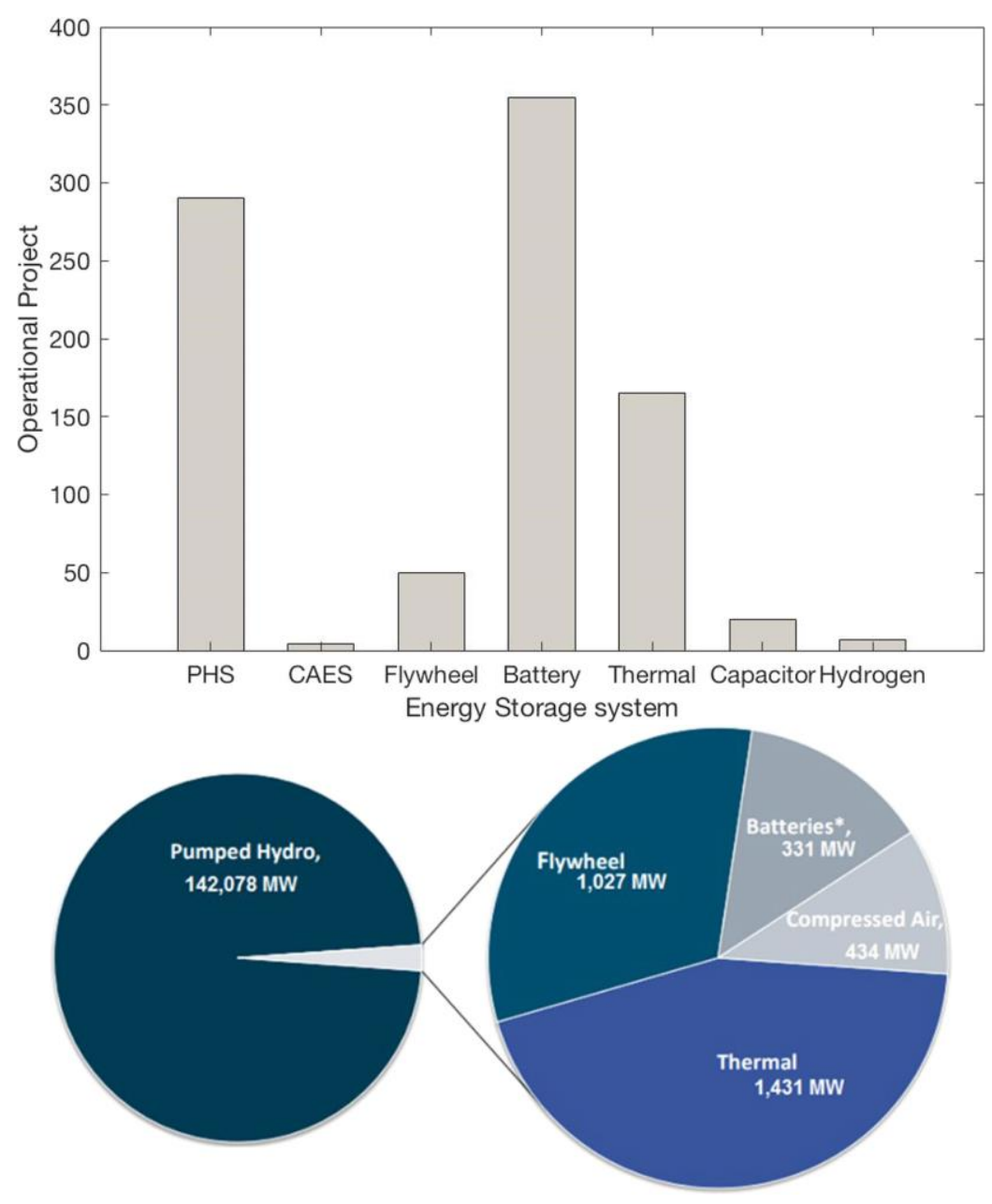

Figure 3. Number of Energy Storage Projects Globally (Up) and Installed Capacity of Energy Storage Worldwide (Down) (Aneke \& Wang, 2016).

Moreover, PHES has over $100 \mathrm{GW}$ of worldwide deployment to provide $100 \%$ renewable power generation at a competitive price and significantly reduce greenhouse gas emissions. The battery type of energy storage is essential for temporary short-time energy storage, electric vehicles and residential/home energy storage. Commonly used battery storage can store approximately $0.13 \mathrm{GWh}$ and storage power of $0.1 \mathrm{GW}$. However, PHES can significantly achieve higher storage capacity. In the Snowy 2.0, the pumped-hydro energy storage project is capable of storing energy up to $350 \mathrm{GWh}$ of energy storage and power of $2 \mathrm{GW}$. Hydroelectric projects on rivers are linked to the majority of PHES that is already existing nowadays. Occasionally, societal solid and environmental opposition is encountered for new hydro projects on waterways. However, PHES systems can be built off channels and closed-loop since most land surface is not near the river. The majority of current PHES are linked to river-based hydroelectric projects. Regardless, there is sometimes much social and environmental opposition for many reasons (Stocks et al., 2019).

As shown in Figure 4, PHES starts work when excess electricity production from renewable energy like wind or solar PV is used to pump water uphill during low-demand times to the upper reservoir. Conversely, when the demand increases and renewable energy sources production drops, water runs downhill through the turbine's upper reservoir and creates electricity. From this concept, the power generation will be more stable, less variable supply results from adding electricity from the turbine to original renewable power. 


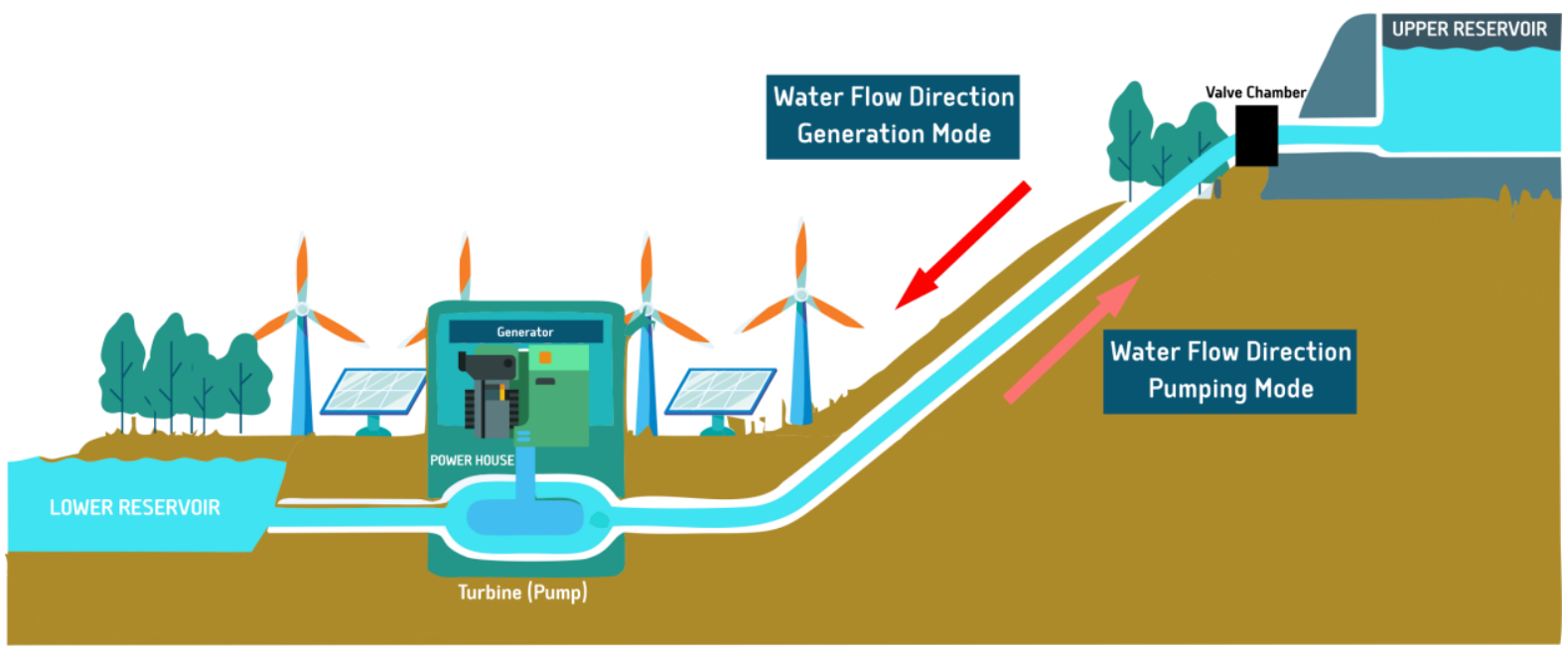

Figure 4. Illustration of pumped hydro energy storage to solve wind and solar PV intermittency (ARENA, 2017; Golande \& Kalgunde 2017; Ecogeneration, 2020).

Indonesia is believed to have an excellent potential for developing this type of storage. Indonesia is estimated to have 26,000 potential sites for PHES with a capacity of storage $821,000 \mathrm{GWh}$ in its mountainous areas (Cheng et al., 2019). A detailed map for the finding by Cheng et al. (2019) of all prospective reservoirs for PHES sites can be seen in Figure 5, while the visualization of potential offriver reservoir pairs can be seen in Figure 6. It would be no surprise if specific locations were rejected based on the local community. Thus, only one out of a thousand identified sites is sufficient to provide an Indonesian renewable power grid for 100 percent. Developers and approval authorities may decide the best sites. However, PHES power generation is based on the rates of water flow, water capacity and section of the water supply (pump/turbine, generator and transmission) depending on the water conveyance's cross-section area. The pumped-hydro system power capacity can be decided mainly independently of the energy storage. Commonly, the power of a PHES system off-river is typically chosen for 5-25 hours to utilize the stored energy.

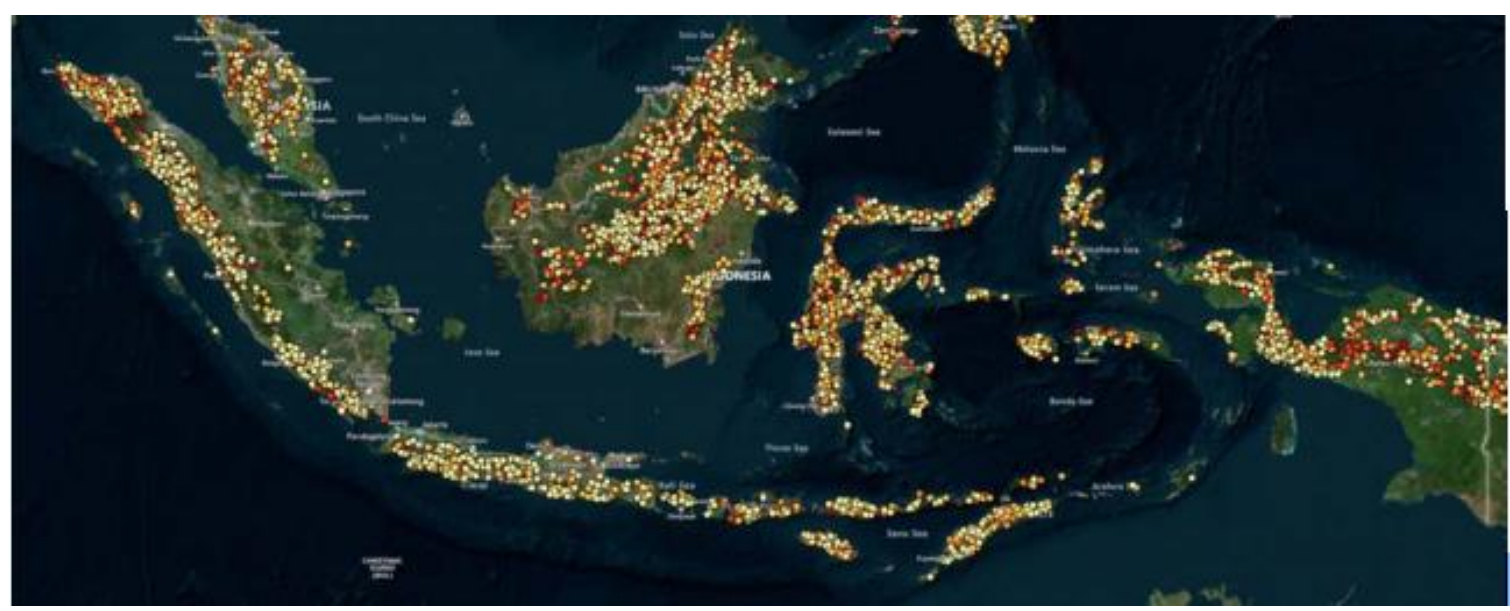

Figure 5. Thousands of off-rivers pumped hydro sites in Indonesia (Cheng et al., 2019).

The renewable energy system mainly relies on solar photovoltaic (PV), wind power, pumped-hydro energy storage and large-area transmission are substantially less than for a corresponding coal-based system because cooling towers are not needed. The pumped-hydro energy storage system requires water for the initial/early fill; after that, replacement of the evaporation losses less rainfall. Cheng et al. (2019) found that the environmental footprint of the off-river pumped-hydro system is commonly relatively small. They also concluded that the reservoirs are significantly smaller $(510 \mathrm{Ha} / \mathrm{GWh})$ than a standard 
river-based system with the enormous amount of available sites that allow for the exclusion of sensitive areas.

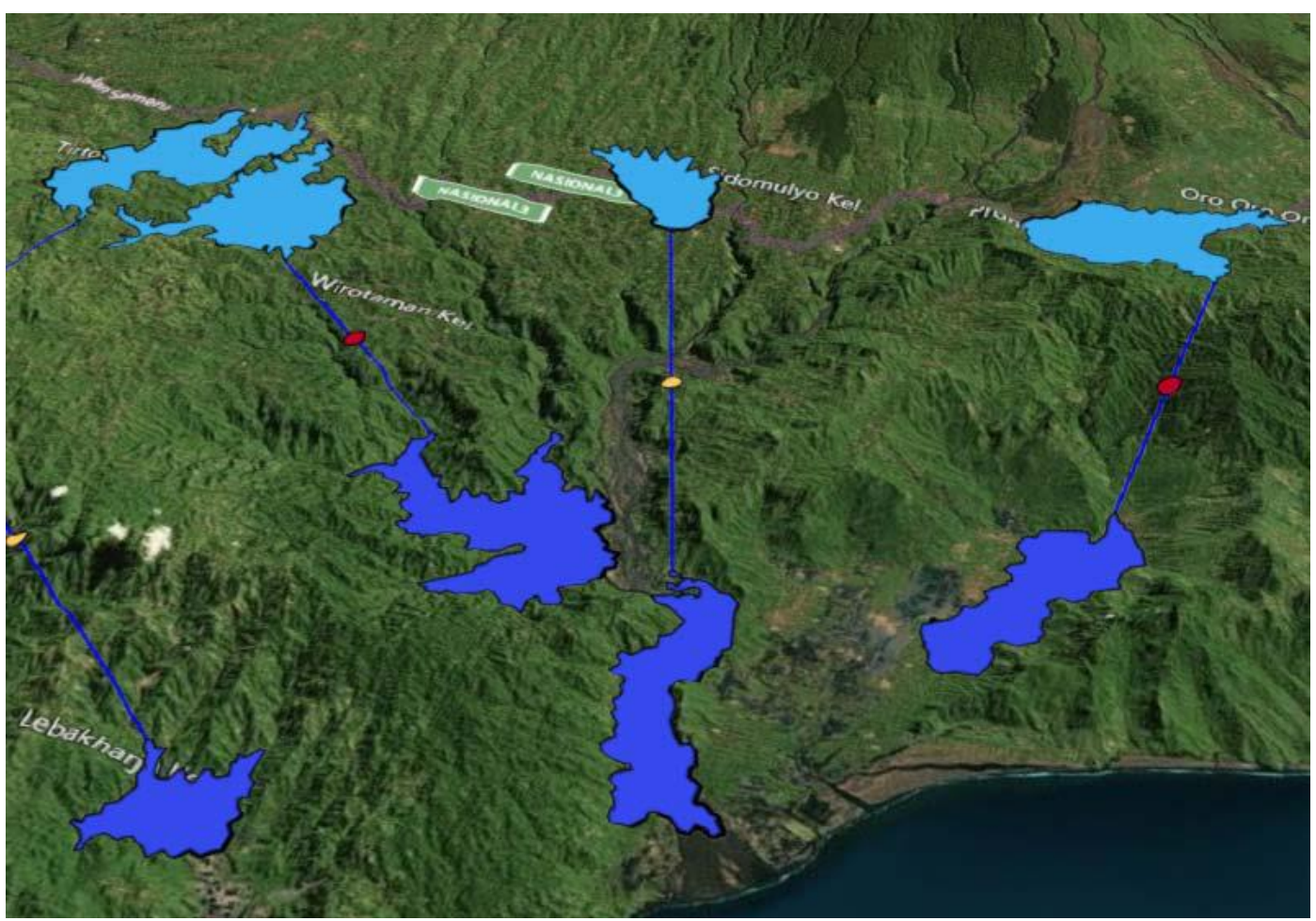

Figure 6. Visualization of potential off-river reservoir pairs in East Java, Indonesia (Cheng et al., 2019).

The area occupied by a pumped-hydro system is significantly smaller rather than wind power farms and solar photovoltaic. Legacy and demand management of fossil fuels can balance the grid with a substantial share of intermittent renewable energy (wind and solar photovoltaic). However, robust storage is required with the renewable fraction approaching 100\%. Pumped-hydro energy storage could provide various services, like inertia, quick ramping and black start capabilities, necessary for maintaining the system (Blakers et al., 2019). This ability helps offset the gap created when coal and gas power plants retire.

\subsection{Compressed Air Energy Storage}

Compressed air energy storage (CAES) is the second-largest capacity energy storage after PHES, which has been proven and used since the 1970s. The CAES system is relatively simple, utilizing electricity from the power grid or renewable sources to power compressors to compress air into underground caves. When electricity is needed and there is no power supply from the generator, compressed air is released to a turbine generator. It expands rapidly through the turbine blades to generate electricity. CAES offer almost constant voltage over the whole charge level, whereas pressure changes substantially while utilizing pressurized air. However, the design of air engines to maintain high efficiencies and enough power over various pressures is technically complicated.

Indonesia has the third-largest gas reserves in the Asia Pacific after Australia and China and is the world's seventh-largest gas exporter (EIA, 2021). Apart from its technological maturity, CAES is suitable to be applied in Indonesia because it can take advantage of abandoned gas reservoirs to store compressed air, such as in the Arun field (Atmadibrata et al. 2019; Raza et al. 2017). CAES can store wind generation surplus energy for later application using compressed air to help alleviate the generation-demand mismatch (Zhang et al., 2021). The illustration of the wind-CAES hybrid system layout project is shown in Figure 7. 
The CAES system has advantages over battery storage technologies in relatively affordable prices, long life, and ease of maintenance (Robinson, 1974). CAES also offer more advantages over traditional batteries, such as extended pressure vessel life and less material toxicity. However, improved pressure vessels are expensive to construct, and safety tests and tests are more costly than batteries generated through mass production. CAES is just as "clean" as the energy source that it stores for electrical storage.

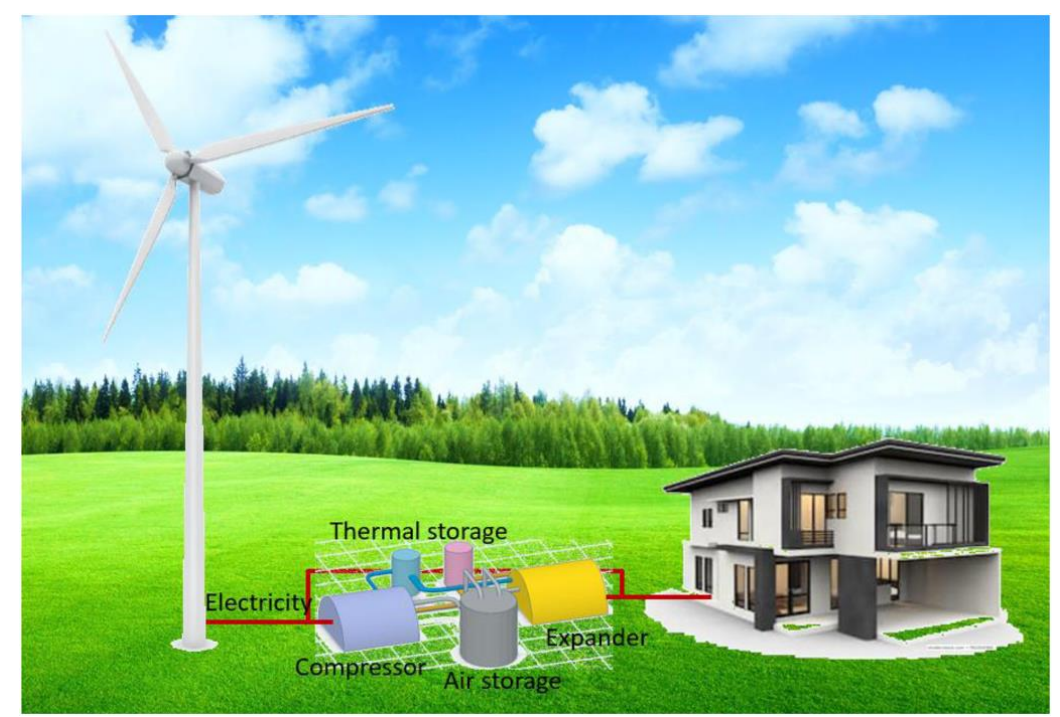

Figure 7. The wind-CAES hybrid system layout (Zhang et al., 2021).

\subsection{Flywheel Energy Storage}

The flywheel energy storage (FES) has a working principle by rapidly rotating the rotor/flywheel and storing the energy as rotational energy in the device. As a result of the energy conservation theory, when power is extracted from the system, the flywheel's rotational speed is reduced; when the energy is added to the storage system, the flywheel's rotational speed is increased. Beacon Power (2006) identified FES as a short-term spinning reserve to balance supply and demand fluctuations and maintain grid frequency. Even though not too long, the advantage in backup speed is suitable for hybrids with renewable sources in Indonesia's climatic conditions, which often change quickly with the arrival of clouds or wind. Limited land, especially in big cities and land conflicts, is also the reason why FES is suitable for application in Indonesia. FES does not require ample space to be placed in substations that are already available in all major cities in Indonesia.

Flywheels have several benefits over conventional energy sources, such as natural gas turbines, including zero carbon emissions, quicker reaction times, also the opportunity to purchase electricity during off-peak hours. The process is quite similar to batteries, but the critical difference is the cost. This type of energy storage can store the energy produced during the off-peak electricity generation period or when the high wind speeds. The FES also not significantly affected by temperature changes. FES can also effectively operate at a much more comprehensive temperature range and not subject to several failures that commonly occur in chemical-based rechargeable batteries with less footprint, primarily made of delicate materials or inert. The flywheels have another advantage: determining the exact amount of energy stored can be delivered with a simple rotation speed measurement.

Unlike conventional/traditional batteries, which have a limited lifespan, FES has the potential to have an endless working lifespan. For example, lithium-ion polymer batteries has only approximately 36 months lifetime. This energy storage system was built as part of James Watt steam engines research that has been continuously working for more than two hundred years. The old flywheels used commonly in pottery and milling can be found in Asia, Africa and Europe. (Donners et al., 2002; Wilson, A. 2002). Nowadays, most modern flywheels typically have sealed devices that need minimal maintenance throughout their sustainability. Like the NASA model, magnetic flywheels in vacuum enclosures 
require no bearing maintenance. Consequently, they are superior to batteries regarding lifetime and energy storage capacity. However, mechanical bearing-based Flywheel systems will have a finite wear life.

The physical shape of batteries-type energy storage can be designed to be paired with a variety of configurations. In contrast, a flywheel must occupy a specified area and volume at a minimum since the energy they store is proportional to its angular mass and its speed of rotation. When the flywheel gets smaller, it also decreases its mass. Therefore, the rate needs to increase; thus, the tension of the material increases. Flywheel will not preferably solution dimensions are a constraint (e.g., under the chassis of a train).

\subsection{Li-ion Battery}

Li-ion battery energy storage is categorized as a mature technology. Nowadays, this type of battery has become one of the most reliable and equally popular energy storage used for backup electricity generation (EESI, 2019). As shown in Figure 8, the Lithium-ion battery is the most common one already used for large-scale energy implementation for portable applications. Indonesia has a very high potential for Nickel and Lithium, which attract domestic and international investors to develop them in a largerscale Li-ion battery (BKPM, 2020).

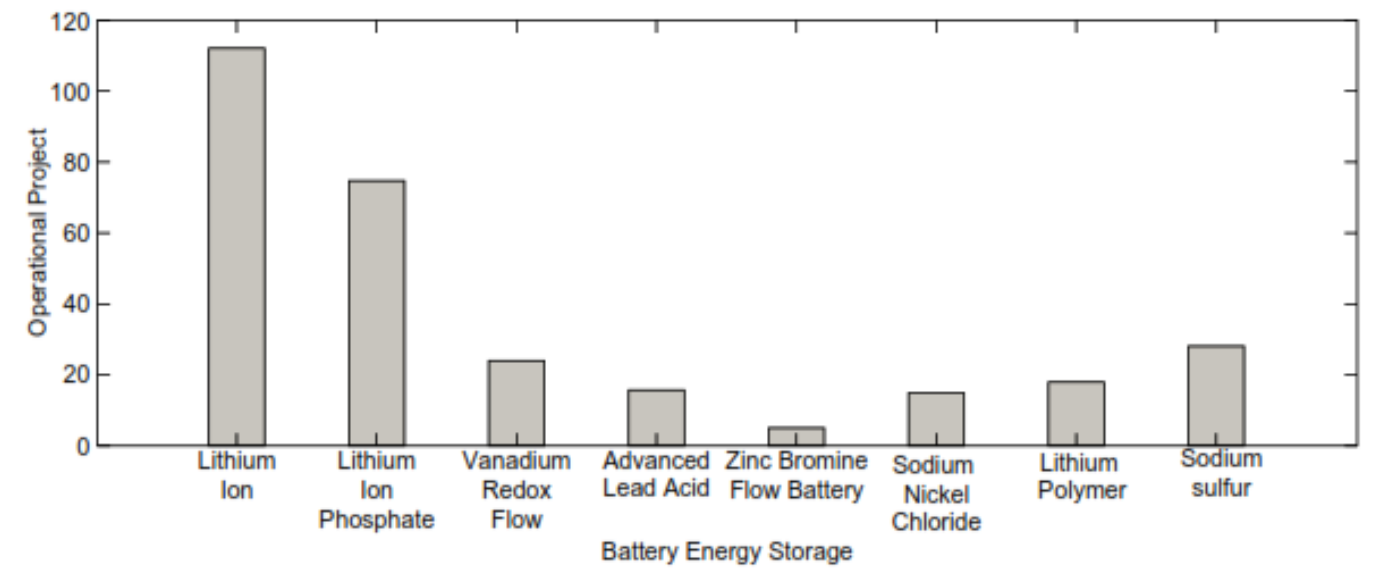

Figure 8. Number of operational projects on energy storage worldwide (Berrada \& Loudiyi, 2019).

According to Akinyele et al. (2014), the Li-ion batteries commonly have a low self-discharge rate, high energy to weight ratio, and desirable efficiency of nearly $100 \%$ (85\%-90\%). So, this type of battery is excellent if combined with wind energy or solar PV to tackle the intermittency. The Li-ion batteries are also very competitive because their weight and size are attractive compared with the lead-acid batteries. It is more lightweight, approximately representing one-fourth of the lead-acid batteries (EPRI-DOE, 2003). Hence this Li-Ion battery is also suitable for application in new and renewable energy grid systems (solar photovoltaic and wind). Li-Ion batteries generally work at a voltage of $4 \mathrm{~V}$ with specific energies between $100 \mathrm{~W} / \mathrm{kg}-150 \mathrm{~W} / \mathrm{kg}$. The current cost of suitable lithium battery commercialization is around USD 900-USD 1,900/kWh (Rastler, 2010).

Indonesia has many lithium mineral resources because Indonesia's archipelago has many active volcanoes. Lithium minerals are formed from magma flows that solidify into granite and montmorillonite clays. However, the main problem with lithium batteries is the nature of the LiFP6 electrolyte-organic solution, which is toxic and flammable. The temporary solution being studied is the use of lithium salts as an alternative to LiFP6 (Danquah et al., 2022).

\section{Lesson Learned from Abroad}

This study identifies four types of energy storage technology suitable for Indonesia's application. As explained in the previous chapter, PHES was chosen because of Indonesia's abundance of geographical resources and rainfall, while CAES is suitable for utilizing abandoned gas reservoirs. Furthermore, FES 
does not require a large land area, so it is appropriate to be placed in densely populated areas like Java Island. At the same time, Li-ion battery is the most popular energy storage, with Indonesia having abundant raw materials to produce it. Several examples of the application of energy storage together with renewable energy are briefly presented in this chapter to show that these technologies can be applied in Indonesia.

\subsection{Pumped Hydro Energy Storage}

A successful example of wind power generation is the El Hierro Project located on El Hierro Island, Canary Islands. The project aims to supply the entire island population with $100 \%$ renewable energy as previously they relied heavily on conventional diesel fuel. This project is a hybrid wind power system with pumped hydro energy storage. The wind farm with a total capacity of $11.5 \mathrm{MW}$ consists of five wind turbines of 2.3 MW each, while the hydroelectric power plant has a total capacity of $11.32 \mathrm{MW}$ from four Pelton turbines of $2.83 \mathrm{MW}$ each. Wind turbines are the primary household electricity supplier. If there is an excess supply, electrical energy is sent to the pumping station to pump water from the lower to the upper. When the wind turbine cannot meet the demand due to low wind gusts, the water in the upper reservoir is launched into the reservoir by gravity to drive a hydroelectric power plant (IRENA, 2020a).

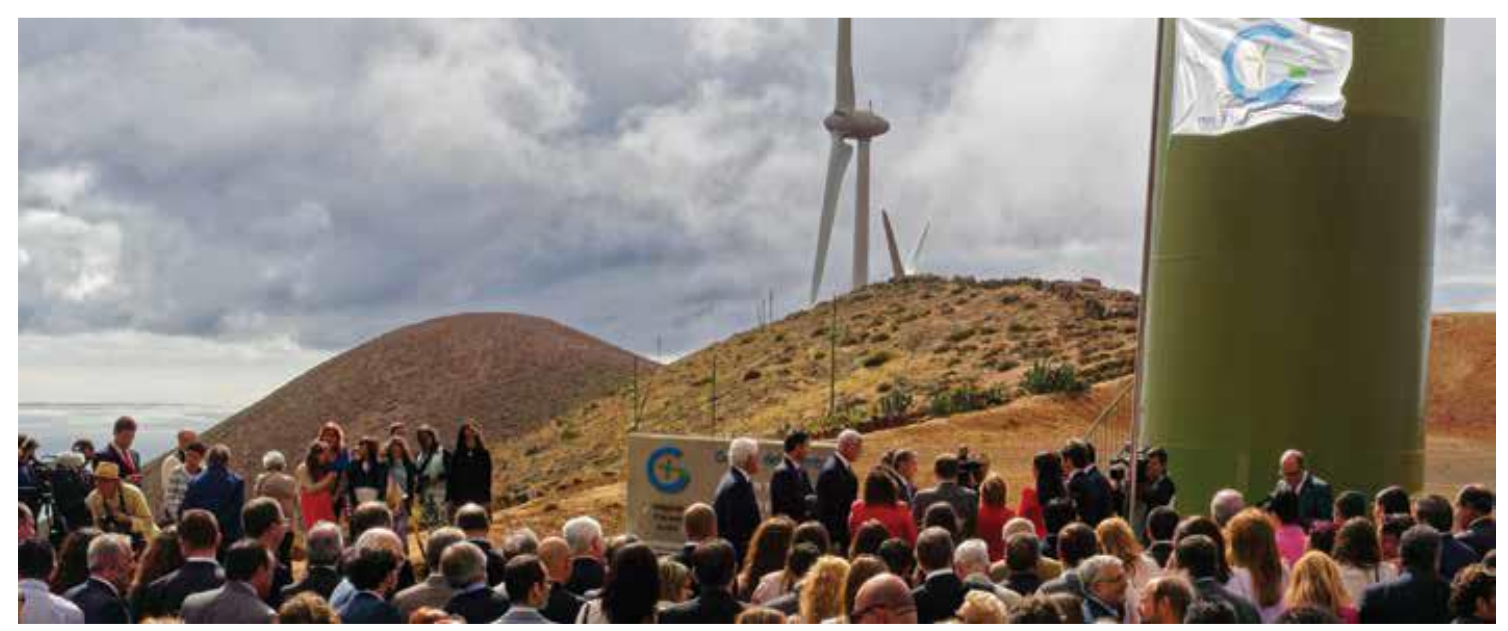

Figure 9. Commissioning of the wind-hydro system in El Hierro (IRENA, 2020a/E.Talbi).

Garcia Latorre et al. (2019) estimates a potential reduction of 6,000 tonnes of diesel and 19,000 tonnes of $\mathrm{CO}_{2}$ in the next 20 years of this project. The El Hierro power plant hybrid system reportedly generated $100 \%$ of electricity from renewable energy for four consecutive hours in 2015, 892 hours in 2017, and 1,450 hours in the early half of 2018 (Gorona del Viento, 2019).

\subsection{Compressed Air Energy Storage}

The current application of CAES is limited because it requires requirements for specific and suitable geological environments. Natural underground caverns for storing compressed air are rare, and studies in keeping the air in cave technology for this application are rare. Only two commercial-scale CAES power plants operate in Huntorf, Germany (290 MW), built-in 1978, and in McIntosh, United States (110 MW) built-in 1991.

Furthermore, IRENA (2020b) reports on a new CAES project with a power of $330 \mathrm{MW}$ being developed in Northern Ireland. A pilot project for the next generation A-CAES has been developed in Switzerland. Another developed technology is Liquid Air Energy Storage (LAES) which uses electricity to cool air to a liquid state and stores the liquid air in cryogenic storage tanks. A LAES demonstration project is underway in the UK, while a commercial LAES project is also being developed in North America (Sampson, 2018). 


\subsection{Flywheel Energy Storage}

In North-Western Australia, in Coral Bay, a 500 kW FES system supports a 600-kW wind farm (3200 $\mathrm{kW}$ systems) and seven $320 \mathrm{~kW}$ diesel generators each (with a total of $2.24 \mathrm{MW}$ ). The FES inertial system ensures periodic energy storage and stabilization of the power grid operation, allowing up to $95 \%$ of energy demand in peak demand periods (Chmielewski et al., 2020). A similar application of the FES system is planned in Marsabit, Kenya, where a 500kW FES store will also be used. It will cooperate with a 550-kW wind farm with and diesel generator system. The FES system used in Kenya will mainly be responsible for stabilizing the power grid operation and ensuring greater RES penetration in the Kenyan power system (Chmielewski et al., 2020).

Like wind and solar power plant, FES systems do not emit $\mathrm{CO}^{2}$. During operation, when powered from renewable energy sources (e.g., wind farms) (Amiryar et al., 2017), they also do not emit pollution into the atmosphere (zero-emission system). However, it is worth considering the carbon footprint of materials used to construct FES systems and other energy storage systems (Chmielewski et al., 2020).

\subsection{Li-ion Battery}

An example of installing energy storage batteries is to support 66 wind turbines with a total capacity of 1,500 kilowatts at Hefeng Wind Farm in China, as shown in Figure 10. A hybrid energy storage system installed to reduce fluctuations in wind power output is a lithium-ion battery system of $5 \mathrm{MW} / 10 \mathrm{MWh}$, $2 \mathrm{MW} / 4 \mathrm{MWh}$ vanadium flow battery system, $2 \mathrm{MW} / 2 \mathrm{MWh}$ vanadium flow battery system, and a supercapacitor (APEC Energy Working Group, 2017).

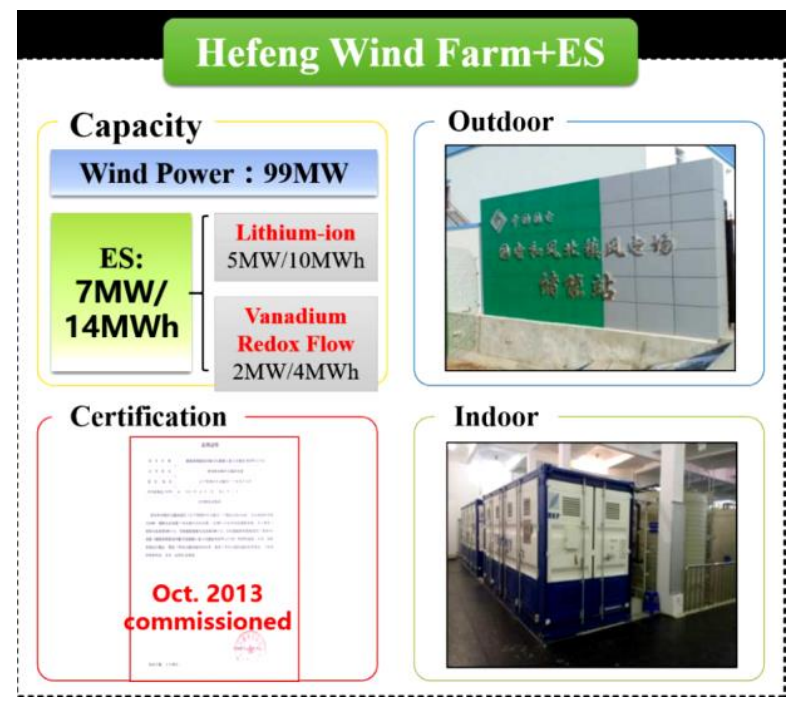

Figure 10. Hefeng wind farm overview (CNESA).

Another example of a large-capacity lithium-ion battery storage system is the Hornsdale Power Reserve located in Jamestown, South Australia, with a storage capacity of $129 \mathrm{MWh}$, as shown in Figure 11. This project was implemented by Tesla and managed by Neoen. This battery storage system supports 99 wind turbines with a capacity of $315 \mathrm{MW}$ connected to a $275 \mathrm{kV}$ network connection with a discharge capacity of 100 MW (Aurecon Group, 2018). 


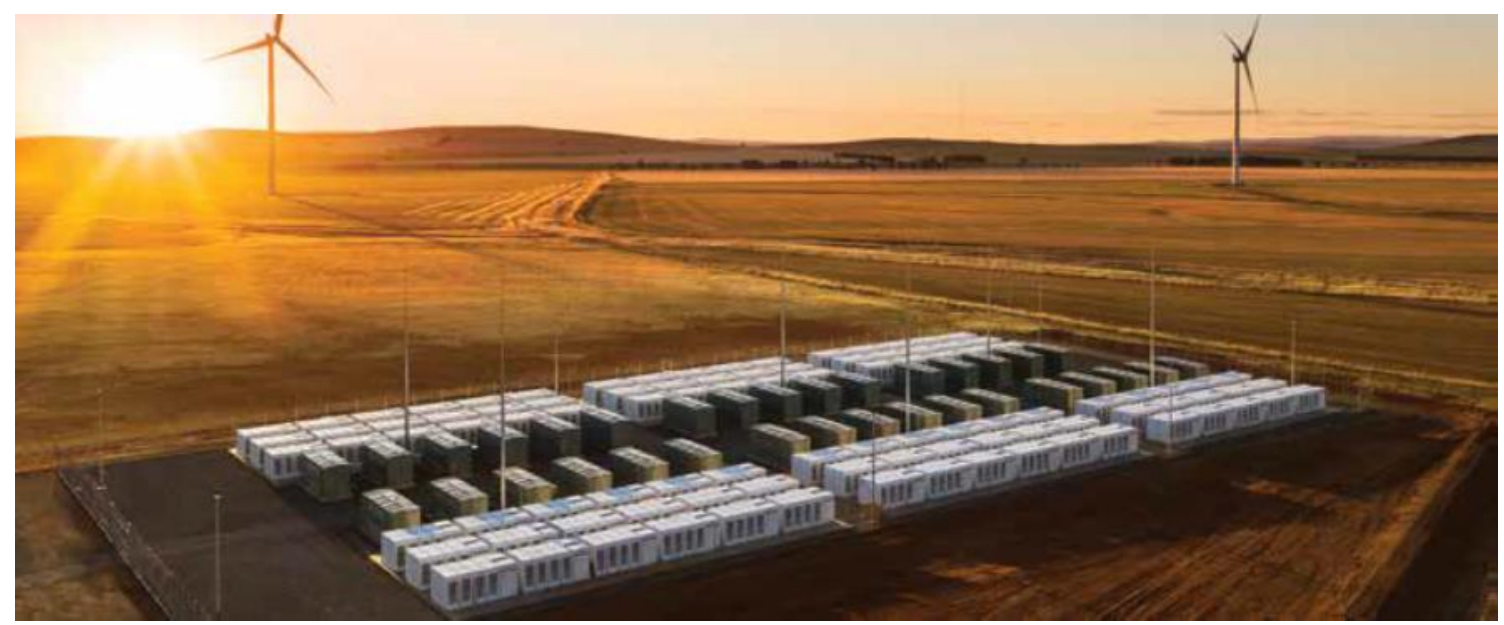

Figure 11. Hornsdale power reserve project in South Australia (Parkinson, 2018).

\section{System Advisor Model}

Modeling and simulations are carried out using the System Advisor Model (SAM) to predict and estimate monthly energy output and leveled electricity costs (LCOE). The modeling calculates the LCOE based on the annual requirement of $20 \mathrm{MW}$ to build a solar power plant without batteries. Summarizing the previous literature review results with hydropower as the best scenario to be applied in Indonesia, this paper will model LCOE to build pumped hydro energy storage with the same capacity of $20 \mathrm{MW}$ as the energy storage to backup PV power generator. Lombok Island is chosen for the model because the island is developing rapidly for renewable energy sources with a solar capacity of $20 \mathrm{MW}$ in 2019 (PLN, 2019).

For the PV module, the authors choose Lombok Island. Average solar radiation in Lombok Island can be seen in Figure 12, while the parameters used for this model are as follows:

1. Location $=$ Zainuddin Abdul Madjid International Airport, Lombok Island

2. Annual average Direct normal beam $=4.49 \mathrm{kWh} / \mathrm{m}^{2} /$ day

3. Module $=$ SunPower SPR-E19-310-COM (Mono-c-Si)

4. Inverter $=$ SMA America: SC750CP-US (with ABB EcoDry Ultra transformer)

5. Total DC / AC capacity $=20,000 \mathrm{kWdc} / 16,940 \mathrm{kWac}$

6. Analysis period $=20$ years

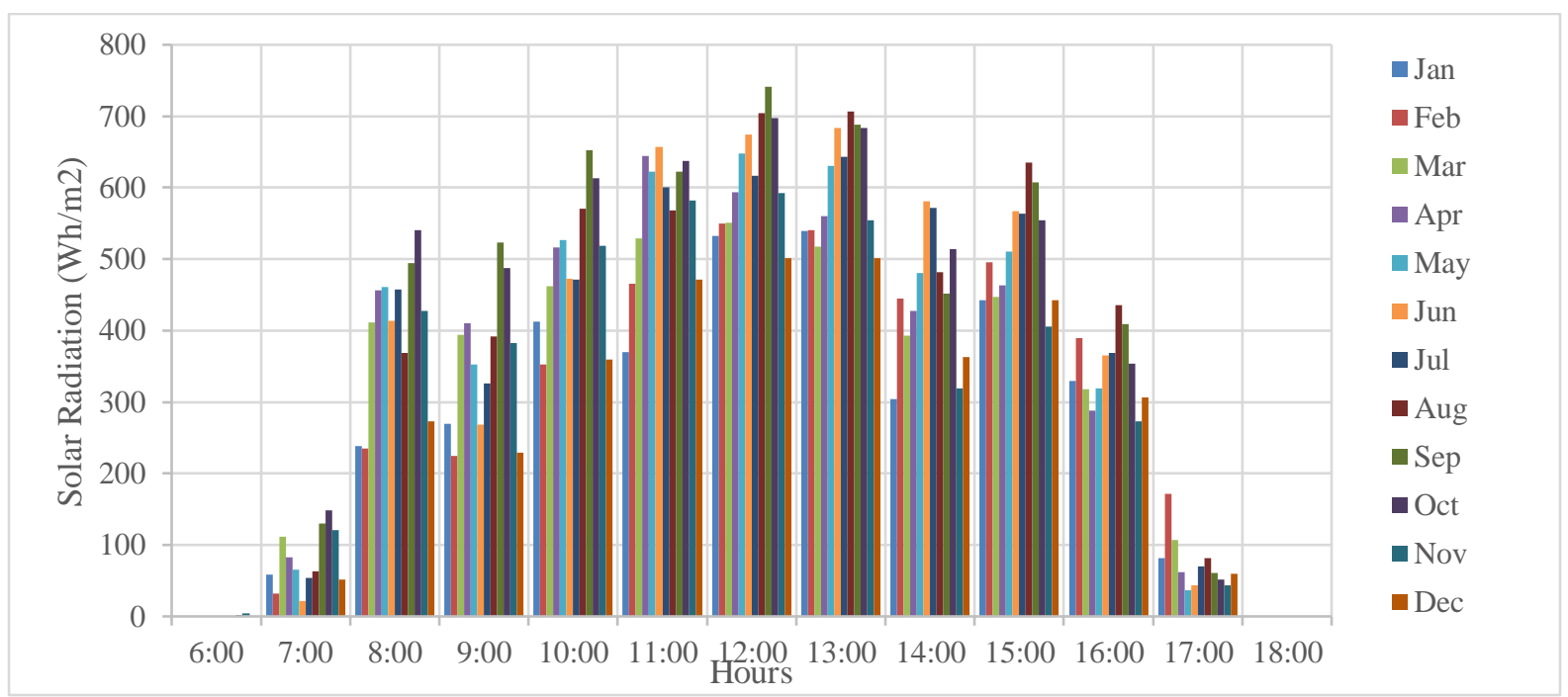

Figure 12. Average solar radiation in Lombok Island (OneBuilding, 2018). 
As for the PV-battery storage used, the additional parameters are:

1. Battery maximum power $=999.999 \mathrm{kWdc}$

2. Battery capacity $=4,000 \mathrm{kWh}$

3. Bank power $=1,000 \mathrm{~kW}$

4. Nominal bank capacity $=3,999.998 \mathrm{kWh}$

The battery is electrochemical energy storage that converts electrical energy into chemical reactions when electricity production from PV exceeds demand. The battery does not generate its own power, so the energy generated in the PV-Battery scenario is the same as PV-only. The results of Solar PV-only modeling can be seen in Figure 13.

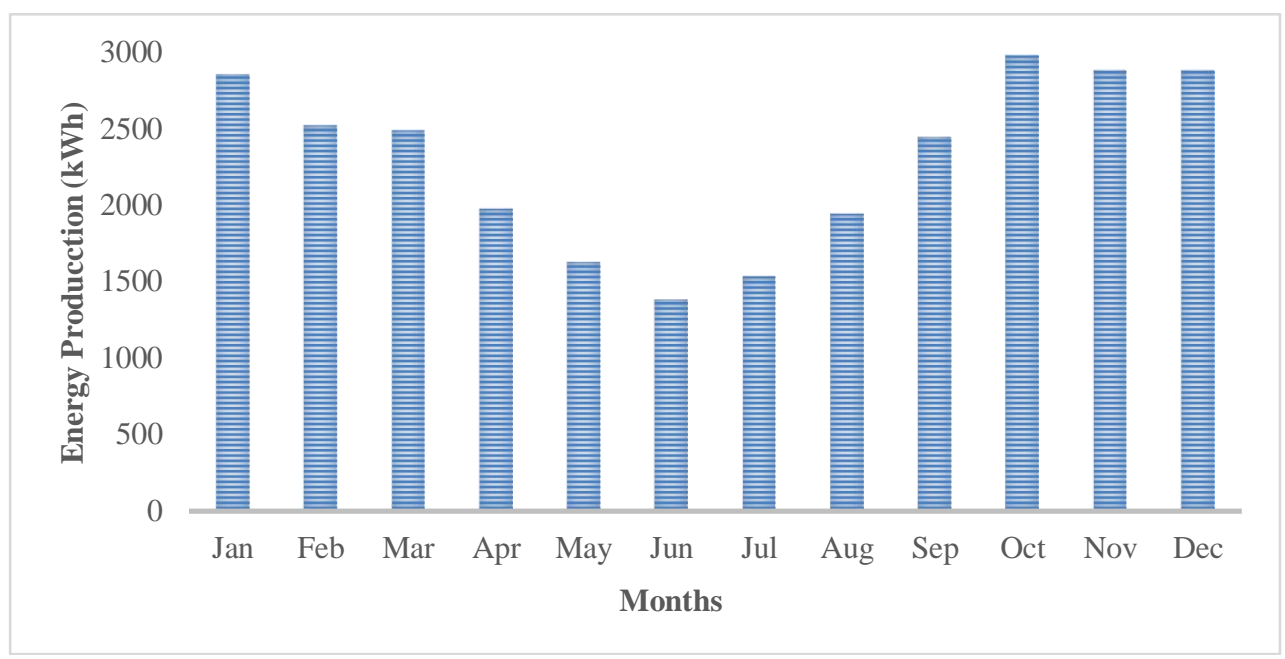

Figure 13. Estimated energy production per month from the solar PV power plant.

The next modeling is a hydropower plant with the following parameters:

1. Power capacity $=20 \mathrm{MW}$

2. Power capital cost $=$ USD $2000 / \mathrm{kW}$ (Barbour et al., 2016)

3. Energy Capital cost $=$ USD $10 / \mathrm{kW}$ (Barbour et al., 2016)

4. System Efficiency (turbine, pump and pipe) $=60.8 \%$ (Nyeche \& Diemuodeke, 2020)

The results of hydro plant modeling can be seen in Figure 14.

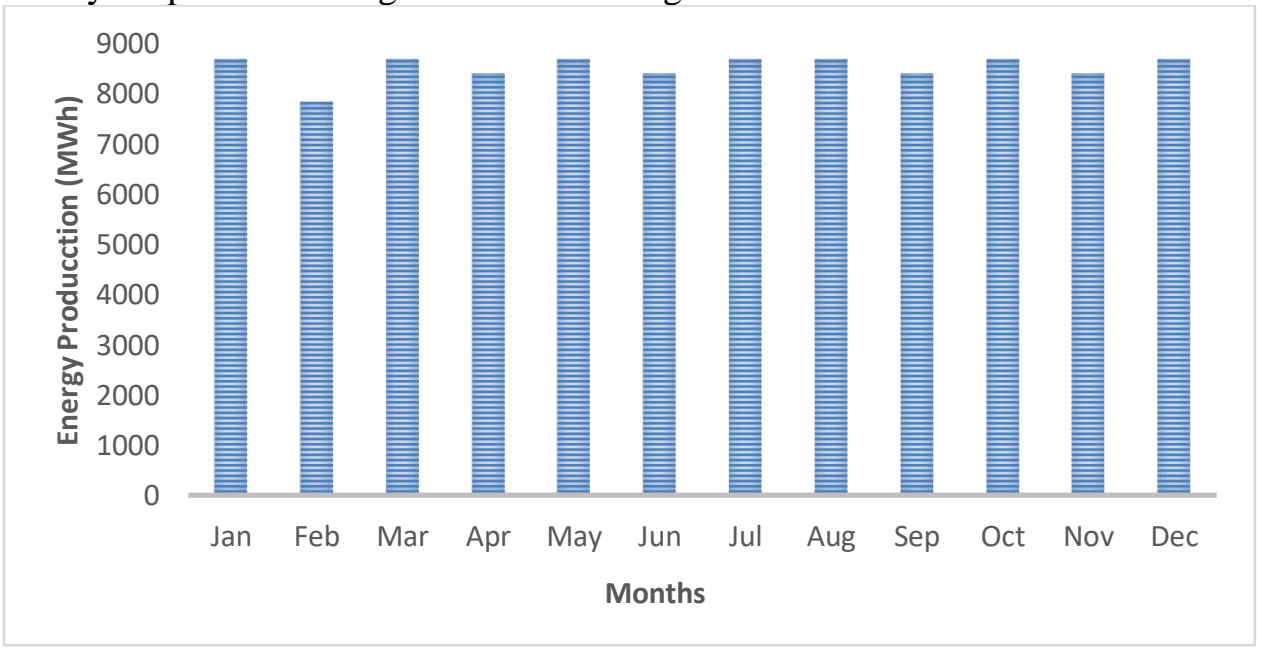

Figure 14. Estimated energy production per month from hydropower plants. 
The economic comparison of a power plant with a capacity of $20 \mathrm{MW}$ using solar PV, solar PV with battery storage, and a hydropower plant can be seen in Table 1 .

Table 2. Economic comparison of the power plant modeled by SAM.

\begin{tabular}{|l|l|l|l|}
\hline \multicolumn{1}{|c|}{ Parameters } & \multicolumn{1}{c|}{ PV } & \multicolumn{1}{c|}{ PV + Battery } & \multicolumn{1}{c|}{ PHES } \\
\hline Capital cost & USD 1,040.00/kW & USD 1,110.00/kW & USD 2,000.00/kW \\
\hline Total capital cost & USD 20,800,924.00 & USD 22,109,528.00 & USD 43,680,000.00 \\
\hline Fixed Operating Cost & USD 180,008.00 & USD 340,000.00 & USD 100,000.00 \\
\hline Annual energy (year 1) & $27,517,292 \mathrm{kWh}$ & $27,375,888 \mathrm{kWh}$ & $102,260,736 \mathrm{kWh}$ \\
\hline Levelized cost of energy & $7.92 \mathrm{c} / \mathrm{kWh}$ & $9.52 \mathrm{c} / \mathrm{kWh}$ & $3.62 \mathrm{c} / \mathrm{kWh}$ \\
\hline
\end{tabular}

\section{Results and Discussion}

The intermittency is one of the primary critical problems in the current implementation of wind and solar PV; during the high demand of energy/peak production of renewable energy, the excess of produced electricity will be stored to the energy storage. Then, during the low demand (low wind speed and night time), the stored energy from the energy storage systems will continue generating electricity. Thus, the supply (power generation) will be more sustainable and stable than deploying renewable energy to fulfill the energy demand by a more reliable, affordable and continuously supply energy system. Energy storage can also help make power safer than using standalone renewables. Unexpected changes in the electricity supply and demand are quickly compensated by energy storage, maintaining a balance between intermittent renewable energy availability and baseload generator operating conditions. In addition, Indonesia adopting the 2015 Paris Agreement related to the carbon tax policy system will impact the increasingly expensive fossil fuel-based power plants. Energy storage systems can help overcome these limitations by enabling optimal integration of renewable energy into the power supply while maintaining grid resilience with the optimal environmental footprint of baseload power generation. Energy storage is less demand for new site development and a resulting reduction in carbon emissions (smaller footprint).

Many types of energy storage technologies have been tested and are in the study stage around the world. However, for application in Indonesia, the Author identifies several technologies that are pretty mature and reliable. Table 2 shows the characteristic properties of currently reliable alternative energy storage. With the character of Lombok Island and other islands in Indonesia with a dense population and high electricity demand, this study proposes PHES as the first choice for energy storage application. The primary consideration in this selection is the abundant resources, supporting geographical contours and high rainfall as a tropical country to be an ideal condition for the dam construction. In addition, PHES has the highest power rating and life cycle compared to other ES, the relatively low capital cost per $\mathrm{kWh}$ and long lifetime. PHES is also mature technology as most of the energy storage in the world is PHES. On the other hand, the disadvantage of this system could be environmental and social issues because it involves water as a basic human need and a large land requirement, so the possibility of social conflict might be high. This risk can be minimized by changing the existing hydro generator or an offriver scheme so that the preferred location is safe and relatively far from the populated area (Stocks et al., 2019). Indonesia is currently developing the Cisokan PHES as the first PHES in Indonesia, and many more are planned in the future.

Furthermore, the second candidate is compressed air energy storage technology, which has a power rating that varies up to $300 \mathrm{MW}$. It is suitable for backing up medium wind energy plants. However, the main drawback of this system is the dependence on specific geographical conditions to store large quantities of high-pressure air (Antonelli et al., 2017). Several ex-gas mining sites such as the Arun field in Aceh are very likely to be used for CAES, but further studies are still needed regarding the types of rock in the reservoir in their suitability for storing compressed air (Atmadibrata et al. 2019; Raza et al. 2017). There are few locations like this field in Indonesia, so it is unlikely that this CAES technology can be applied. Besides CAES, the Li-ion battery is a technology developing rapidly and is the fastest 
way to provide energy storage in a relatively short time. Unfortunately, battery energy storage (BES) is only ideal for small electronic equipment but has not been proven for large capacities. Field testing for this is currently underway, and some issues still need to be fixed, such as high initial costs and safety issues related to large-scale use and disposal (Hussain et al., 2019). The high initial price also hinders the development of flywheel energy storage in Indonesia, apart from a relatively short service life, making these two technologies not recommended for use in Indonesia.

Table 3. Characteristic properties of current Energy Storage System (Fathima \& Palanisamy, 2018).

\begin{tabular}{|c|c|c|c|c|c|c|c|c|c|c|}
\hline ESS & $\begin{array}{c}\text { Power } \\
\text { rating } \\
(\mathbf{M W})\end{array}$ & $\begin{array}{c}\text { Discharge } \\
\text { time }\end{array}$ & $\begin{array}{c}\text { Power } \\
\text { density } \\
(\mathbf{W} / \mathbf{L})\end{array}$ & $\begin{array}{c}\text { Energy } \\
\mathbf{d e n} \\
(\mathbf{W h} / \mathbf{L})\end{array}$ & $\begin{array}{c}\text { Response } \\
\text { time }\end{array}$ & $\begin{array}{c}\text { Capital cost } \\
\text { (USD/kWh })\end{array}$ & $\begin{array}{c}\text { Efficiency } \\
(\%)\end{array}$ & $\begin{array}{c}\text { Self- } \\
\text { discharge per } \\
\text { day }(\%)\end{array}$ & $\begin{array}{c}\text { Life- } \\
\text { time } \\
\text { (years) }\end{array}$ & $\begin{array}{c}\text { Life-time } \\
\text { (Cycles) }\end{array}$ \\
\hline PHS & $100-5,000$ & $1-24 \mathrm{~h}$ & $0.1-0.2$ & $0.2-2$ & Minutes & $5-100$ & $70-80$ & Very small & $>50$ & $>15,000$ \\
\hline CAES & $5-300$ & $1-24 \mathrm{~h}$ & $0.2-0.6$ & $2-6$ & Minutes & $2-50$ & $41-75$ & Small & $>25$ & $>10,000$ \\
\hline FESS & 0.25 & $\begin{array}{c}\text { Seconds- } \\
\text { hours }\end{array}$ & 5,000 & $20-80$ & $<$ Seconds & $1,000-5,000$ & $80-90$ & 100 & $15-20$ & $104-107$ \\
\hline NiCd & $0-40$ & $\begin{array}{c}\text { Seconds- } \\
\text { hours }\end{array}$ & $75-700$ & $15-80$ & $<$ Seconds & $800-1,500$ & $60-80$ & $0.2-0.6$ & $5-20$ & $1,500-$ \\
\hline Li-ion & $0-0.1$ & $\begin{array}{c}\text { Seconds- } \\
\text { hours }\end{array}$ & $\begin{array}{c}1,300- \\
10,000\end{array}$ & $200-400$ & $<$ Seconds & $600-2,500$ & $65-75$ & $0.1-0.3$ & $5-100$ & $600-$ \\
1,200 \\
\hline
\end{tabular}

This study conducts a simulation of renewable energy system design and project economics model using SAM software to validate the hypothesis of these renewable systems. Then, as a comparison of modeling results, the Author uses data published by IRENA (2019). The modeling results show that constructing a solar power plant is affordable, around USD 1 for every watt of capacity. This price is down 11\% compared to the 2018 price of USD 1,192/watt (IRENA 2019; IRENA 2021). Moreover, the LCOE price for this model is $7.92 \mathrm{c} / \mathrm{kWh}$, lower than the previously estimated price of $8.5 \mathrm{c} / \mathrm{kWh}$. This price decline is consistent with the previous trend of a 77\% decline from 2010 to 2018.

Next, in the second model of solar PV with Li-ion battery, the installation costs increased by about $11 \%$ to USD $1.11 /$ watt, and the LCOE increased by $20 \%$ to $9.52 \mathrm{c} / \mathrm{kWh}$. Another interesting finding is the slightly lower annual energy produced by PV and battery of 27,375,888 kWh than 27,517,292 kWh produced by PV only. This decrement of power might be associated with battery efficiency, where the energy from PV is converted to the electrochemical process and vice versa. The electricity from the PV panel distributed directly has less electricity loss than via battery as energy storage. In addition, the fixed maintenance cost also increased by more than 85\% to USD 340,000.00 compared to PV-only of USD 180,000.00. Although expensive, Energy storage technology is crucial if a solar PV plant is built off-grid. Conversely, if solar PV is part of the on-grid system, batteries are relatively unnecessary and only add to the cost component. Also, the short average lifespan of the $\mathrm{Li}$-ion battery is only 2-3 years or 300-500 cycles, of course, should be considered (Tektronix, n.d.). Even with the highest prediction of 5-10 years by Fathima \& Palanisamy (2018), the costs required are not unexpensive for renewal and maintenance every year. Thus, storage solutions with a long lifetime and low maintenance need to be considered.

The last modeling is to estimate the economic review of a PHES for a hybrid with solar PV, so it assumes a similar capacity of $20 \mathrm{MW}$. The simulation results show that the LCOE as the economic indicator is only $3.62 \mathrm{c} / \mathrm{kWh}$ even though it has the highest capital cost of USD 43,680,000.00. This lower LCoE is because of its mature technology and long life so that it has the lowest maintenance and operating cost while producing the highest energy throughout the year (IRENA 2021). Combined with solar PV, the total capital cost of this hybrid power plant is USD 64,480,924.00. However, if it is assumed that solar PV supplies electricity for 12 hours during the day, and PHES supplies electricity in the next half-day, the LCOE is $5.77 \mathrm{c} / \mathrm{kWh}$. This low price is, of course, a significant advantage for both consumers and electricity producers. Moreover, the average lifespan of PHES is more than 50 years, which is an advantage that other power plants do not have, even if they are fossil generators. 


\section{Conclusions}

Indonesia is an archipelagic country located on the equator with excellent solar and wind power generation potential. However, the development of these two types of renewable power plants is still lacking. One of the challenges is the government's less ambitious target in the future national energy mix. Another most obvious challenge of wind and solar power generation is the intermittent nature of their natural sources. The sun is only available during the day, and if there are clouds, the quality of the energy produced will be reduced. Likewise, wind gusts are erratic depending on air temperature, weather and geographic location. This intermittent problem wreaks havoc on the entire electrical system if solar and wind power plants are connected to the grid. It also provides fluctuating electricity to consumers when installed in an off-grid network.

Implementing an energy storage system is a proposed solution to solar and wind energy intermittently. Li-ion batteries are the most widely used hybrid with solar and wind generators. However, Li-ion batteries are only used for lower capacities up to $10 \mathrm{MW}$. In addition, the relatively short lifespan of $\mathrm{Li}$-ion batteries compared to the investment period makes them unsuitable for large-capacity generators. PHES is the most realistic choice to be implemented in Indonesia from the available energy storage technologies. The scattered high terrains in Indonesia are estimated to have great potential for developing PHES in the future. In addition, PHES is the most widely applied energy storage technology worldwide, with $98 \%$ of worldwide capacity using this technology. So, it is hoped that the development of this technology will not encounter many obstacles.

PHES has been implemented in many countries and has proven effective when hybridizing with intermittent energy sources in off-grid networks such as in El Hierro, Canary Islands. Successful examples for PHES can also be drawn from the USA, Australia, China, and Japan for on-grid applications (IHA, 2018). Thus, more study on applying this technology to Indonesia is proposed with Upper Cisokan as the pilot project. The type of energy storage that has received a lot of attention, namely $\mathrm{Li}$-ion batteries for large-scale energy storage, is also worthy of further study, mainly because Indonesia has a lot of potential for raw materials. Furthermore, CAES can also be an option if appropriate geological resources are proven along with established technology.

From the modeling that has been done, the PV-only scenario requires the cheapest initial cost regardless is only applicable for on-grid plans. The PV battery is more suitable for off-grid applications but with an additional capital cost of almost $10 \%$. In addition, this second scenario requires virtually double the maintenance cost than PV-only, so the LCOE increases to $9.52 \mathrm{c} / \mathrm{kWh}$ compared to $7.92 \mathrm{c} / \mathrm{kWh}$. On the other hand, it was found that the capital cost of PHES is more than double while the hybrid PV and PHES cost three times that PV-only plant. However, many benefits can be obtained, including cheaper LCOE and a longer lifetime. Thus, the overall feasibility of the project increases. Although energy storage is not the only solution for increasing renewable energy development in Indonesia, it is clear that solar and wind energy development will face more challenges in the future without hybrid energy storage planning.

\section{Acknowledgments}

This research did not receive any specific grant from funding agencies in the public, commercial, or not-for-profit sectors.

\section{References}

Adam, K. B., \& Miyauchi, H. (2019). Optimal planning of solar PV using simple model for new feedin tariff in Indonesia. 2019 International Seminar on Intelligent Technology and Its Application (ISITIA), 171-176. https://doi.org/10.1109/ISITIA.2019.8937209

Ajami, W. A., Arief, A., \& Nappu, M. B. (2019). Optimal power flow for power system interconnection considering wind power plants intermittency. International Journal of Smart Grid and Clean Energy, 8(3), 372-376. https://doi.org/10.12720/sgce.8.3.372-376 
Akinyele, D. O., \& Rayudu, R. K. (2014) Review of energy storage technologies for sustainable power networks. Sustainable Energy Technology and Assessment, 8, 74-91.

Al Badwawi, R., Abusara, M., \& Mallick, T. (2015). A review of hybrid solar PV and wind energy system. Smart Science, 3(3), 127-138. https://doi.org/10.1080/23080477.2015.11665647

Al Hakim, R. R. (2020). Model energi Indonesia, tinjauan potensi energi terbarukan untuk ketahanan energi di Indonesia: Sebuah ulasan. Jurnal Pengabdian Kepada Masyarakat, 1(1).

Al Matin, M. A., Takeda, S., Tanaka, Y., Sakurai, S., \& Tezuka, T. (2019). LCOE analysis for gridconnected pv systems of utility scale across selected ASEAN countries. ERIA Discussion Paper Series, 305.

Alifia, T., \& Fraser, K. (2021). Achieving renewable energy targets: The impact of residential solar PV prosumers in Indonesia. International Journal of Sustainable Energy Planning and Management, $32,111-124$.

Amiryar, M. E., \& Pullen, K. R. (2017) A review of flywheel energy storage system technologies and their applications, Applied Science, 7, 286. https://doi.org/10.3390/app7030286

Aneke M., \& Wang, M. (2016). Energy storage technologies and real-life applications - A state of the art review. Applied Energy, 179. 350-377. https://doi.org/10.1016/j.apenergy.2016.06.097

Antonelli, M., Barsali, S., Desideri, U., Giglioli, R., Paganucci, F., \& Pasini, G. (2017). Liquid air energy storage: Potential and challenges of hybrid power plants. Applied Energy, 194, 522-529. https://doi.org/10.1016/j.apenergy.2016.11.091

APEC Energy Working Group (2017). Research on energy storage technologies to build sustainable energy systems in the APEC Region. Asia-Pacific Economic Cooperation Secretariat.

Arafah, W., Nugroho, L., Takaya, R., \& Soekapdjo, S. (2018). Marketing strategy for renewable Energy development in Indonesia context today. International Journal of Energy Economics and Policy, | 8(5), 181-186. https://www.econjournals.com/index.php/ijeep/article/view/6844

ARENA (2017). What is pumped hydro and how does it work?. Australian Renewable Energy Agency. https://arena.gov.au/blog/what-is-pumped-hydro-and-how-does-it-work/

Atmadibrata, R., Muslim, D., Hirnawan, R. F., \& Abdurrokhim, A. (2019). Characteristics of Arun carbonate reservoir and its implication to optimize the most potential gas resource zone in Arun gas field, Aceh, Indonesia. Indonesian Journal on Geoscience, 6(2), 209-222. https://doi.org/10.17014/ijog.6.2.209-222

Aurecon Group (2018), Hornsdale power reserve: Year 1 technical and market impact case study.

Barbour, E., Wilson, I. A. G., Radcliffe, J., Ding, Y., \& Li, Y. (2016). A review of pumped hydro energy storage development in significant international electricity markets. Renewable and Sustainable Energy Reviews, 61, 421-432. https://doi.org/10.1016/j.rser.2016.04.019

Beacon Power Corporation. (2006). Flywheel-based solutions for grid reliability. https://web.archive.org/web/20070712140640/

http://www.beaconpower.com/products/EnergyStorageSystems/docs/BeaconPower solutions grid. pdf

BKPM. (2020). Battery cell brochure 2020. https://www.bkpm.go.id/images/uploads/printing/Battery_Cell_Brochure_2020.pdf

Blakers, A., Stocks, M., Lu, B., Cheng, C., \& Stocks, R. (2019). Pathway to 100\% renewable electricity. IEEE Journal of Photovoltaics, 9(6), 1828-1833. https://doi.org/10.1109/JPHOTOV.2019.2938882

Blum, N. U., Wakeling, R. S., \& Schmidt, T. S. (2013). Rural electrification through village gridsAssessing the cost competitiveness of isolated renewable energy technologies in Indonesia. Renewable and Sustainable Energy Reviews, 22, 482-496.

BPPT (2019). Indonesia Energy Outlook 2019.

BPPT (2020). Outlook Energi Indonesia 2020.

Braff, W.A, Mueller, J. M., \& Trancik, J. (2016). Value of storage technologies for wind and solar energy. Nature Climate Change, 6, 964.

Burke, P. J., Widnyana, J., Anjum, Z., Aisbett, E., Resosudarmo, B., \& Baldwin, K. G. H. (2019). Overcoming barriers to solar and wind energy adoption in two asian giants: India and Indonesia. Energy Policy 132, 1216-1228. https://doi.org/10.1016/j.enpol.2019.05.055

Cheng, C., Blakers, A., Stocks, M., \& Lu, B. (2019). Pumped hydro energy storage and 100\% renewable electricity for East Asia. Global Energy Interconnection, 2(5), 386-392. https://doi.org/10.1016/j.gloei.2019.11.013 
Chmielewski A., Kupecki J., Szabłowski Ł., Fijałkowski K.J., Zawieska J., Bogdziński K., Kulik O., \& Adamczewski, T. (2020). Currently available and future methods of energy storage. WWF Poland.

Danquah, S. A., Strimaitis, J., Denize, C. F., Pradhan, S. K., \& Bahoura, M. (2022). LLCZN/PEO/LiPF6 composite solid-state electrolyte for safe energy storage application. Batteries, $8(1), 3$. https://doi.org/10.3390/BATTERIES8010003

Donners, K., Waelkens, M., \& Deckers, J. (2002). Water mills in the area of Sagalassos: A disappearing ancient technology. Anatolian Studies. 52, 1-17. https://doi.org/10.2307/3643076

Drouineau, M., Assoumou, E., Mazauric, V., \& Maïzi, N. (2015). Increasing shares of intermittent sources in Reunion Island: Impacts on the future reliability of power supply. Renewable and Sustainable Energy Reviews, 46, 120-128.

Dwipayana, Garniwa, I., \& Herdiansyah, H. (2021). Sustainability index of solar power plants in remote areas in Indonesia. Technology and Economics of Smart Grids and Sustainable Energy, 6(1). https://doi.org/10.1007/s40866-020-00098-0

Ecogeneration (2020). NSW pumped hydro plant could unlock new England renewable energy Zone. https://www.ecogeneration.com.au/nsw-pumped-hydro-plant-could-unlock-new-englandrenewable-energy-zone/

EESI. (2019). Fact sheet energy storage. https://www.eesi.org/papers/view/energy-storage-2019

EPRI-DOE. (2003). Handbook of energy storage for transmission \& distribution applications.

European Commission. (2017). Energy storage - the role of electricity. https://ec.europa.eu/energy/sites/ener/files/documents/swd2017_61_document_travail_service_part 1 1_66.pdf

Fairuz, R., Setiawan, E. A., \& Hernanda, I. (2018). Mapping and analysis of initial cost against levelized cost of energy for fesidential PV pooftoop in Indonesia. E3S Web of Conferences, 67, 4-8. https://doi.org/10.1051/e3sconf/20186701024

Fathima, A. H., \& Palanisamy, K. (2018). Renewable systems and energy storages for hybrid systems. Hybrid-Renewable Energy Systems in Microgrids: Integration, Developments and Control, 147164.

Garcia Latorre, F. J., Quintana, J. J., \& de la Nuez, I. (2019), Technical and economic evaluation of the integration of a wind-hydro system in El Hierro island, Renewable Energy, 134, 186-93.

Golande, S., \& Kalgunde, M. (2017). Energy storage using pumped hydro storage based on standalone photovoltaic power generation system. IEEE International Conference on Power, Control, Signals and Instrumentation Engineering (ICPCSI-2017).

Gorona del Viento. (2019). The wind-hydro-pumped station of El Hierro. www.goronadelviento.es

Gür, T. M. (2018). Review of electrical energy storage technologies, materials and systems: Challenges and prospects for large-scale grid storage. Energy and Environmental Science, 11(10), 2696-2767. https://doi.org/10.1039/c8ee01419a

Habibie, M. N., Sasmito, A., \& Kurniawan, R. (2011). Kajian Potensi Energi Angin di Wilayah Sulawesi dan Maluku. Jurnal Meteorologi Dan Geofisika, 12(2).

Hallgren, W., Gunturu, U. B., \& Schlosser, A. (2014). The potential wind power resource in Australia: a new perspective. PloS One, 9(7), e99608.

Handayani, N. A., \& Ariyanti, D. (2012). Potency of solar energy applications in Indonesia. International Journal of Renewable Energy Development, 1(2), 33-38. https://doi.org/10.14710/ijred.1.2.33-38

Hardianto, H. (2019). Utilization of solar power plant in indonesia: A Review. International Journal of Environment, Engineering and Education, 1(3), 1-8.

Hasan, M. H., Mahlia, T. M. I., \& Nur, H. (2012). A review on energy scenario and sustainable energy in Indonesia. Renewable and Sustainable Energy Reviews, 16(4), 2316-2328. https://doi.org/10.1016/j.rser.2011.12.007

Hidayatno, A., Destyanto, A. R., \& Handoyo, B. A. (2019). A conceptualization of renewable energypowered industrial cluster development in Indonesia. Energy Procedia, 156(September 2018), 7-12. https://doi.org/10.1016/j.egypro.2018.11.074

Holder, M. (2017), Highview wins $£ 1.5 \mathrm{~m}$ backing for liquid air energy storage. BusinessGreen. www.businessgreen.com/bg/news/3014913/highview-wins-gbp15m-funding-for-new-hybridliquidair-energy-storage-system 
Hussain, F., Rahman, M. Z., Sivasengaran, A. N., \& M. Hasanuzzaman. (2019). Energy storage technologies. Energy for Sustainable Development: Demand, Supply, Conversion and Management, $125-65$.

IEA. (2021), Energy Storage. IEA. https://www.iea.org/reports/energy-storage

IHA. (2018). The world's water battery: Pumped hydropower storage and the clean energy transition.

IRENA. (2017). Renewable energy prospects: Indonesia. International Renewable Energy Agency (IRENA). https://www.irena.org/publications/2017/Mar/Renewable-Energy-Prospects-Indonesia

IRENA. (2019). Renewable power generation costs in 2018. International Renewable Energy Agency.

IRENA. (2020a), Electricity storage valuation framework: Assessing system value and ensuring project viability. International Renewable Energy Agency.

IRENA. (2020b), Innovation outlook: Thermal energy storage. International Renewable Energy Agency.

IRENA (2021). Renewable power generation costs in 2020. International Renewable Energy Agency.

Irfan, M., Zhao, Z., Ahmad, M., \& Rehman, A. (2019). A techno-economic analysis of off-grid solar PV system: A case study for Punjab Province in Pakistan. Processes, 7(10), 708.

Kadang, J. M., \& Windarta, J. (2021). Optimasi sosial-ekonomi pada pemanfaatan PLTS PV untuk energi berkelanjutan di Indonesia. Jurnal Energi Baru Dan Terbarukan, 2(2), 74-83.

Kemenhut. (2018). Penyelenggaraan dan Pelaporan Inventarisasi Gas Rumah Kaca Nasional.

Kusakana, K. (2015). Operation cost minimization of photovoltaic-diesel-battery hybrid systems. Energy, 85, 645-653.

Liu, Z. (2015). Clean energy replacement and electricity replacement. Global Energy Interconnection, 65-90. https://doi.org/10.1016/B978-0-12-804405-6.00002-6

Martosaputro, S., \& Murti, N. (2014). Blowing the wind energy in Indonesia. Energy Procedia, 47, 273-282. https://doi.org/10.1016/j.egypro.2014.01.225

McCormick, P. G., \& Suehrcke, H. (2018). The effect of intermittent solar radiation on the performance of PV systems. Solar Energy, 171, 667-674.

MEMR. (2013). 3 Pembangkit listrik tenaga surya (PLTS) resmi beroperasi. https://www.esdm.go.id/id/media-center/arsip-berita/3-pembangkit-listrik-tenaga-surya-plts-resmiberoperasi

MEMR. (2019). Peluang besar kejar target EBT melalui energi surya. https://ebtke.esdm.go.id/post/2019/09/26/2348/peluang.besar.kejar.target.ebt.melalui.energi.surya

MEMR. (2021). Capaian kinerja 2020 dan target 2021. https://www.esdm.go.id/assets/media/content/content-capaian-kinerja-tahun-2020-dan-programkerja-tahun-2021-sektor-esdm.pdf

Muliadi, Ruwaidah, E., \& Asyari, A. (2015). Mapping potential for wind energy in coastal marine. ASEAN Journal of Systems Engineering, 3(1), 37-40.

Nababan, W., Sihombing, H. V., Kawai, H., \& Ambarita, H. (2019). Contribution of solar photovoltaic on the reduction of greenhouse sas emission in the Indonesia power sector. IOP Conference Series: Materials Science and Engineering, 648(1), 12028. https://doi.org/10.1088/1757$\underline{899 X / 648 / 1 / 012028}$

Noviani, L. (2019). Assessment of the wind power application in Indonesia. Indonesian Journal of Physics and Nuclear Application, 4(3), 78-85. https://doi.org/10.24246/ijpna.v4i3.78-85

Nyeche, E. N., \& Diemuodeke, E. O. (2020). Modelling and optimisation of a hybrid PV-wind turbinepumped hydro storage energy system for mini-grid application in coastline communities. Journal of Cleaner Production, 250, 119578. https://doi.org/10.1016/j.jclepro.2019.119578

NYISO. (2017). The state of storage. https://www.nrdc.org/experts/miles-farmer/nyisos-flawed-planthreatens-slow-energy-storage

OneBuilding. (2018). http://climate.onebuilding.org/WMO Region 5 Southwest Pacific/IDN Indonesia/index.html

Outhred, H., \& Retnanestri, M. (2015). Insights from the experience with solar photovoltaic systems in Australia and Indonesia. Energy Procedia, 65, 121-130. https://doi.org/10.1016/j.egypro.2015.01.044

Pandyaswargo, A. H., Ruan, M., Htwe, E., Hiratsuka, M., Wibowo, A. D., Nagai, Y., \& Onoda, H. (2020). Estimating the energy demand and growth in off-grid villages: Case studies from Myanmar, Indonesia, and Laos. Energies, 13(20), 5313. 
Parkinson, G. (2018), Deep dive into first year of Tesla big battery at Hornsdale. RenewEconomy. https://reneweconomy.com.au/deep-dive-into-first-year-of-tesla-big-battery-at-hornsdale-93479/

PLN. (2019). Rencana usaha penyediaan tenaga listrik PT Perusahaan Listrik Negara (Persero) tahun 2019 sampai dengan tahun 2028.

https://gatrik.esdm.go.id//assets/uploads/download_index/files/5b16d-kepmen-esdm-no.-39-k-20mem-2019-tentang-pengesahan-ruptl-pt-pln-2019-2028.pdf

Pristiandaru, D. L., \& Pambudi, N. A. (2019). Wind energy in Indonesia : Current status, potential, challenge, opportunities, and future policy. Indonesian Journal of Energy, 2(2), 65-73.

Purba, N. P., Kelvin, J., Annisaa, M., Teliandi, D., Ghalib, K. G., Resti Ayu, I. P., \& Damanik, F. S. (2014). Preliminary research of using ocean currents and wind energy to support lighthouse in small island, Indonesia. Energy Procedia, 47, 204-210. https://doi.org/10.1016/j.egypro.2014.01.215

Purwanto, W. W., Nugroho, Y.S., Dalimi, R., \& Adlina, T. A. (2006). Indonesia energy outlook and statistics 2006.

https://www.researchgate.net/publication/288827409_Indonesia_Energy_Outlook_and_Statistics_ 2006? channel=doi\&linkId=5684ab2408ae1e63f1f1d49c\&showFulltext=true

Rastler, D. (2010). Electricity energy storage technology options. Final report. EPRI.

Raza, A., Gholami, R., Rezaee, R., Bing, C. H., Nagarajan, R., \& Hamid, M. A. (2017). Preliminary assessment of $\mathrm{CO} 2$ injectivity in carbonate storage sites. Petroleum 3(1), 144-54. https://doi.org/10.1016/j.petlm.2016.11.008

Rehman, S., Al-Hadhrami, L. M., \& Alam, M. M. (2015). Pumped hydro energy storage system: A technological review. Renewable and Sustainable Energy Reviews, 44, 586-598. https://doi.org/10.1016/j.rser.2014.12.040

Ren, G., Liu, J., Wan, J., Guo, Y., \& Yu, D. (2017). Overview of wind power intermittency: Impacts, measurements, and mitigation solutions. Applied Energy, 204(October), 47-65. https://doi.org/10.1016/j.apenergy.2017.06.098

Retnanestri, M., \& Outhred, H. (1993). Off-grid photovoltaic applications in Indonesia : An analysis of preliminary fieldwork experience. 1-10.

Robinson, A. L. (1974) Energy storage (I): using electricity more ifficiently. Science, 184, 785-787.

Rumbayan, M., Abudureyimu, A., \& Nagasaka, K. (2012). Mapping of solar energy potential in Indonesia using artificial neural network and geographical information system. Renewable and Sustainable Energy Reviews, 16(3), 1437-1449. https://doi.org/10.1016/j.rser.2011.11.024

Sampson, J. (2018), Highview power and SNC-Lavalin announce collaboration to deploy liquid air energy storage. Gasworld. www.gasworld.com/highviewpower-and-snc-lavalin-collaborate-todeploylaes/2014291.article

Sari, D. P., \& Kusumaningrum, W. B. (2014). A technical review of building integrated wind turbine system and a sample simulation model in Central Java, Indonesia. Energy Procedia, 47, 29-36. https://doi.org/10.1016/j.egypro.2014.01.193

Sarjiya, Budi, R. F. S., \& Multanto, L. P. (2020). Achieving new and renewable energy target: A case study of java-bali power system, Indonesia. 2020 2nd International Conference on Smart Power and Internet Energy Systems (SPIES), 560-565. https://doi.org/10.1109/SPIES48661.2020.9242984

Sector, V. P. (2012). Wind power. Green Energy and Technology, 20(5), 231-256. https://doi.org/10.1007/978-3-642-20951-2 8

Shezan, S. K. A., Al-Mamoon, A., \& Ping, H. W. (2018). Performance investigation of an advanced hybrid renewable energy system in Indonesia. Environmental Progress and Sustainable Energy, 37(4), 1424-1432. https://doi.org/10.1002/ep.12790

Short, W., Packey, D. J., \& Holt, T. (1995). A manual for the economic evaluation of energy efficiency and renewable energy technologies. National Renewable Energy Laboratory. https://www.nrel.gov/docs/legosti/old/5173.pdf

Sipil, D. (2019). Rencana usaha penyediaan tenaga listrik (RUPTL) 2019-2028. Perusahaan Listrik Negara. https://www.pln.co.id/kementerian

Soonmin, H., Lomi, A., Okoroigwe, E. C., \& Urrego, L. R. (2019). Investigation of solar energy: The case study in Malaysia, Indonesia, Colombia and Nigeria. International Journal of Renewable Energy Research, 9(1). https://doi.org/10.20508/ijrer.v9i1.8699.g7620

Sovacool, B. K. (2009). The intermittency of wind, solar, and renewable electricity generators: Technical barrier or rhetorical excuse?. Utilities Policy, 17(3-4), 288-296. 
Stich, J., Mannhart, M., Zipperle, T., Massier, T., Huber, M., \& Hamacher, T. (2014). Modelling a lowcarbon power system for Indonesia, Malaysia and Singapore. 1-11.

Stocks, M., Blakers, A., Cheng, C., \& Lu, B. (2019). Towards 100\% Renewable Electricity for Indonesia: The Role for Solar and Pumped Hydro Storage. 2019 International Conference on Technologies and Policies in Electric Power and Energy.

Sukarso, A. P., \& Kim, K. N. (2020). Cooling effect on the floating solar PV: Performance and economic analysis on the case of west Java province in Indonesia. Energies, 13(9). https://doi.org/10.3390/en13092126

Syanalia, A., \& Winata, F. (2018). Decarbonizing energy in Bali with solar photovoltaic: GIS-based evaluation on grid-connected system. Indonesian Journal of Energy, 1(2), 5-20. https://doi.org/10.33116/ije.v1i2.22

Tambunan, H. B., Hakam, D. F., Prahastono, I., Pharmatrisanti, A., Purnomoadi, A. P., Aisyah, S., Wicaksono, Y., \& Sandy, I. G. R. (2020). The challenges and opportunities of renewable energy source (RES) penetration in Indonesia: Case study of java-bali power system. Energies, 13(22), 5903. https://doi.org/10.3390/en13225903

Tarigan, E., \& Purba, L. (2014). Assessment of PV power generation for household in Surabaya using solarGIS-pvPlanner simulation. Energy Procedia, 47, 85-93.

Tarigan, E., Djuwari, \& Kartikasari, F. D. (2015). Techno-economic simulation of a grid-connected PV system design as specifically applied to residential in Surabaya, Indonesia. Energy Procedia, 65, 9099. https://doi.org/10.1016/j.egypro.2015.01.038

Tektronix. n.d. Lithium-ion battery maintenance guidelines.

The Republic of Indonesia. (2014). Peraturan Pemerintah No. 79 Tahun 2014 tentang Kebijakan Energi Nasional. https://jdih.esdm.go.id/index.php/web/result/186/detail

The Republic of Indonesia. (2016a). First nationally determined contribution Republic of Indonesia. https://www4.unfccc.int/sites/ndcstaging/PublishedDocuments/Indonesia-First/First-NDCIndonesia_submitted to UNFCCC Set_November 2016.pdf

The Republic of Indonesia. (2016b). Undang-Undang Republik Indonesia Nomor 16 Tahun 2016 tentang Pengesahan Paris Agreement to The United Nation Framework Convention on Climate Change (Persetujuan Paris atas Konvensi Kerangka Kerja Perserikatan Bangsa-Bangsa mengenai Perubahan Iklim). https://www.bphn.go.id/data/documents/16uu016.pdf

The Republik of Indonesia. (2017). Peraturan Presiden Republik Indonesia Nomor 22 Tahun 2017. https://www.esdm.go.id/assets/media/content/content-rencana-umum-energi-nasional-ruen.pdf

Umam, M. F., Muhammad, F., Adityatama, D. W., \& Purba, D. P. (2018). Tantangan pengembangan energi panas bumi dalam perannya terhadap ketahanan energi di Indonesia. Swara Patra 8(3):4856.

Umam, M. F., Saputro, F. P., Al Asyari, M. R., Selia, S., Sunaryo, A. F., \& Yuliatin, U. (2021). Performance analysis of $120 \mathrm{KWp}$ grid-connected rooftop solar photovoltaic system in Central Java. MigasZoom, 3(2), 67-80. https://doi.org.10.37525/MZ/2021-2/298

Van Kooten, G. C. (2010). Wind power: the economic impact of intermittency. Letters in Spatial and Resource Sciences, 3(1), 1-17.

Wilson, A. (2002). Machines, power and the ancient economy. The Journal of Roman Studies 92, 132. https://doi.org/10.2307/3184857

World Nuclear Association. (2020). Electricity and energy storage. https://www.worldnuclear.org/information-library/current-and-future-generation/electricity-and-energy-storage.aspx

World Bank. (2007). Technical and economic assessment of off-grid, mini-grid and grid electrification technologies. ESMAP Paper. https://openknowledge.worldbank.org/handle/10986/17456

Zhang, X., Qin, C., Xu, Y., Li, W., Zhou, X., Li, R., Huang, Y., Chen, H. (2021). Integration of smallscale compressed air energy storage with wind generation for flexible household power supply. Journal of Energy Storage, 37, 102430. https://doi.org/10.1016/j.est.2021.102430 